Article

\title{
Syntheses of Sulfo-Glycodendrimers Using Click Chemistry and Their Biological Evaluation
}

\author{
Yoshiko Miura $^{1,2, *}$, Shunsuke Onogi ${ }^{2}$ and Tomohiro Fukuda ${ }^{2,3}$ \\ 1 Department of Chemical Engineering, Graduate School of Engineering, Kyushu University, \\ 744 Motooka, Nishi-ku, Fukuoka 819-0395, Japan \\ 2 School of Materials Science, Japan Advanced Institute of Science and Technology, 1-1 Asahidai, \\ Nomi, Ishikawa 923-1292, Japan \\ 3 Department of Applied Chemistry and Chemical Engineering, Toyama National College of \\ Technology, Hongo-campus, 13 Hongo-Machi, Toyama, Toyama 939-8630, Japan \\ * Author to whom correspondence should be addressed; E-Mail: miuray@chem-eng.kyushu-u.ac.jp; \\ Tel.: +81-92-802-2749; Fax: +81-92-802-2769.
}

Received: 23 July 2012; in revised form: 5 September 2012 / Accepted: 18 September 2012 / Published: 9 October 2012

\begin{abstract}
A series of novel glycol-clusters containing sulfonated $N$-acetyl-D-glucosamine (GlcNAc) have been synthesized using click chemistry. Three dendrimers with aromatic dendrons were synthesized using chlorination, azidation and click chemistries. The resulting dendrimers were modified with azide-terminated sulfonated GlcNAc using click chemistry. The sulfonated dendrimers showed affinity for proteins, including the lectin wheat germ agglutinin and amyloid beta peptide (1-42). The dendrimers of G1 and G2 in particular showed the largest affinity for the proteins. The addition of the sulfonated GlcNAc dendrimers of G1 and G2 exhibited an inhibition effect on the aggregation of the amyloid beta peptide, reduced the $\beta$-sheet conformation, and led to a reduction in the level of nanofiber formation.
\end{abstract}

Keywords: glycopolymer; dendrimer; click chemistry; amyloidosis

\section{Introduction}

Saccharides displayed on the surfaces of cells have been the subject of considerable attention because they can play important roles in living systems [1]. Furthermore, they have been related to a 
variety of different biological activities, including cell-cell adhesion, protein recognition, pathogen infection, and cancer metastasis. For these reasons, materials capable of interfering with the functions of these saccharides are being considered for use in the fabrication of new biomaterials and the development of new drugs [2]. Saccharide-protein interactions, however, are usually too weak to be used as drugs and biomaterials.

Interestingly, it is well known that saccharide-protein interactions can be amplified by multivalency, otherwise known as "the cluster glycoside effect" [3,4]. Clusters of glycosides can amplify the interaction though multiple saccharide binding interactions to the proteins, and increase the binding probability. A variety of different compounds containing multivalent saccharides have been reported to show strong molecular recognition abilities. Furthermore, several saccharide containing substances have been reported such as artificial glycoprotein conjugates, glycopeptides, saccharide-thin layers and saccharide nanoparticles [5-11]. Of these saccharide containing substances, polymers with saccharide side chains have attracted the most pronounced level of attention because of the large cluster glycoside effects associated with their saccharide-protein interactions. Throughout the remainder of this paper, these polymers will be referred to as "glycopolymers". These glycopolymers are interesting because they exhibit a strong amplification effect and possess properties making them practical candidates for applications as biomaterials and polymer drug development.

We previously reported the synthesis of a variety of different glycopolymers for lectin recognition, toxin neutralization and cell cultivation [12]. Although these glycopolymers were interesting materials, it was difficult to clarify the detailed mechanism of their interactions, because of the complicated nature of polymer structure resulting from the variable molecular weight and monomer sequence distributions in the copolymers. Of the glycopolymers synthesized and evaluated to date, glycodendrimers possess some of the most interesting characteristics as a consequence of their uniform structure and their extensive molecular recognition ability, with the general expectation that these materials could ultimately be applied as potential polymer drugs [13].

Recently, we reported the synthesis of a sulfonated glycopolymer that interacted with Alzheimer amyloid $\beta(\mathrm{A} \beta)$ and inhibited its aggregation [14,15]. The sulfonated glycopolymer behaved as a mimic of glycosaminoglycans (GAGs) such as heparin and heparan, and interacted with A $\beta$ like GAGs. In the current research, novel glycodendrimers containing a sulfonated saccharide unit were investigated for their ability to inhibit the aggregation of the $A \beta$ (1-42) peptide. Glycodendrimers possess well-defined structures that are generally believed to be more suitable and therefore better suited for use in medicinal applications than liner polymers. The synthesis of the dendrimers in the current report represents one of the key highlights of this research paper because the dendrimers were successfully constructed using click chemistry rather than the tedious multi-step synthetic strategies typically used in the synthesis of these materials [16]. Several dendrimers were synthesized in this way and their inhibitory effects on $\mathrm{A} \beta$ aggregation investigated by fluorescence, circular dichroism (CD) spectra, and atomic force microscopy (AFM).

The interactions of these glycodendrimers with wheat germ agglutinin (WGA) were also investigated to clarify the properties of novel cluster glycosides. Since the interactions between the A $\beta$ and GAGs were predominately electrostatic in nature, the synthetic sulfonated glycodendrimer was envisaged to interact with the $A \beta$ in the same way. WGA has a positive net charge in neutral buffer solution [17], and the interaction of the glycodendrimers with WGA was considered to occur though 
both the molecular recognition of $N$-acetyl-D-glucosamine (GlcNAc) [18] and electrostatic interactions. The interaction with WGA was investigated in view of the $A \beta$ interaction. The ultimate propose of this study was the fabrication of a glycocluster capable of inhibiting $A \beta$ aggregation.

\section{Results and Discussion}

\subsection{Synthesis of Dendrimers with 6-Sulfo-GlcNAc}

Glycodendrimers of G1 and G2 (Figure 1) were synthesized using click chemistry according to the divergent method depicted in Schemes 1-7.

Figure 1. Chemical structures of the saccharide-derivatives.

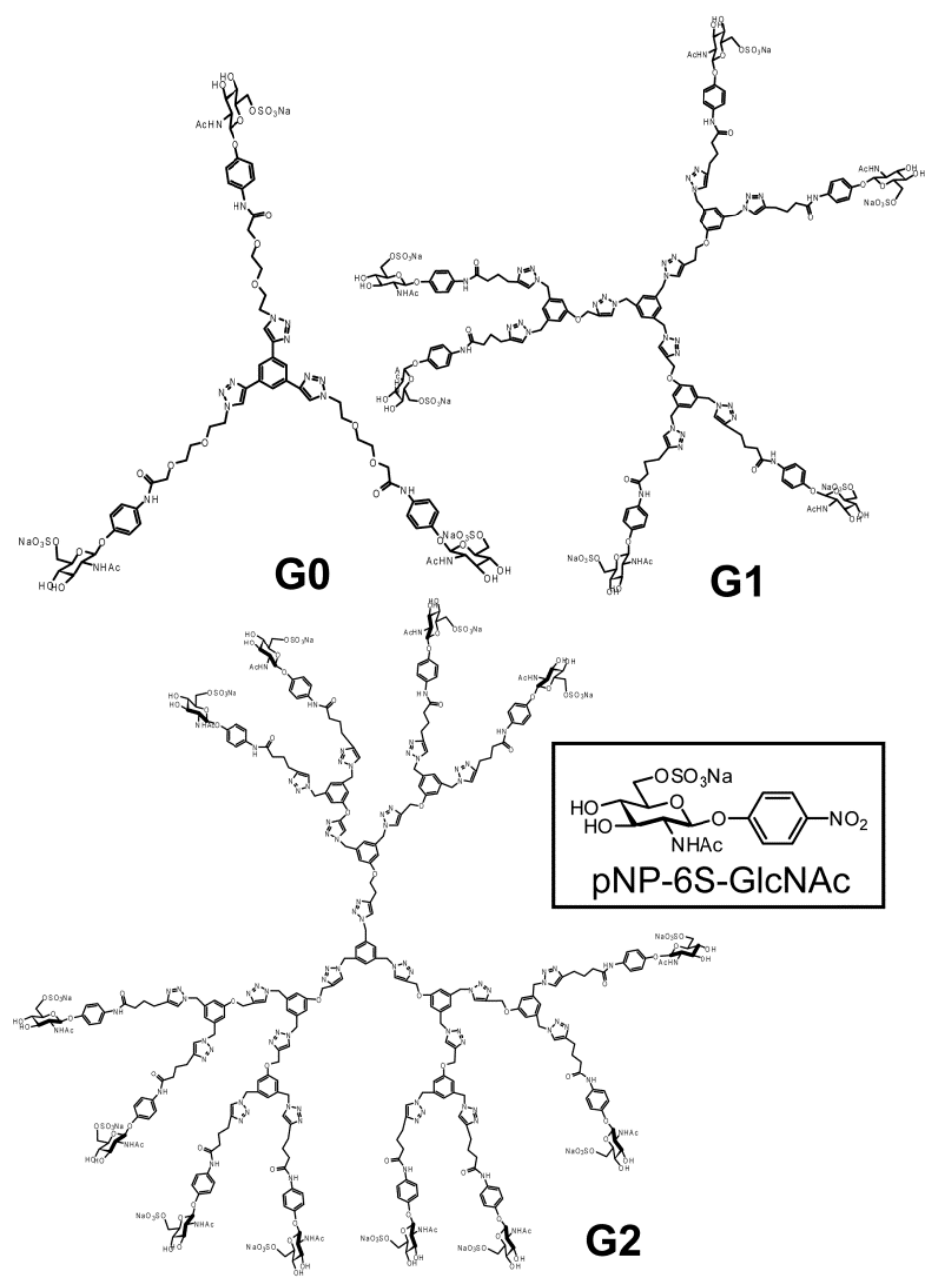

The trimer of 6-sulfo-GlcNAc (G0) was synthesized via the connection of azide-terminated 6-sulfoGlcNAc to 1,3,5-triethynylbenzene, using click chemistry [19,20] (Schemes 1 and 2). p-Aminophenyl6-sulfo-D-GlcNAc was synthesized according to a method previously reported in the literature $[14,15]$ and subsequently connected to $N$-phenylhex-5-ynamide using 2-(7-aza- $1 H$-benzotriazole-1-yl)-1,1,3,3tetramethyl uranium hexafluorophosphate (HATU) and N,N-diisopropylethylamine (DIEA) (Scheme 3). Starting from 5-hydroxyisophthalic acid, the dendron of 1,3-bis(chloromethyl)-5-(prop-2-yn-1yloxy)benzene was synthesized by sequential alkylation, hydrogenation and chlorination reactions, with the resulting dendron being attained in high yield (G1-N $\mathbf{N}_{\mathbf{3}}$ : 93\%, G2-N $\mathbf{3}$ : 56\%) (Schemes 4 and 5). 
Scheme 1. Syntheses of azide-terminated sulfonated GlcNAc 7.
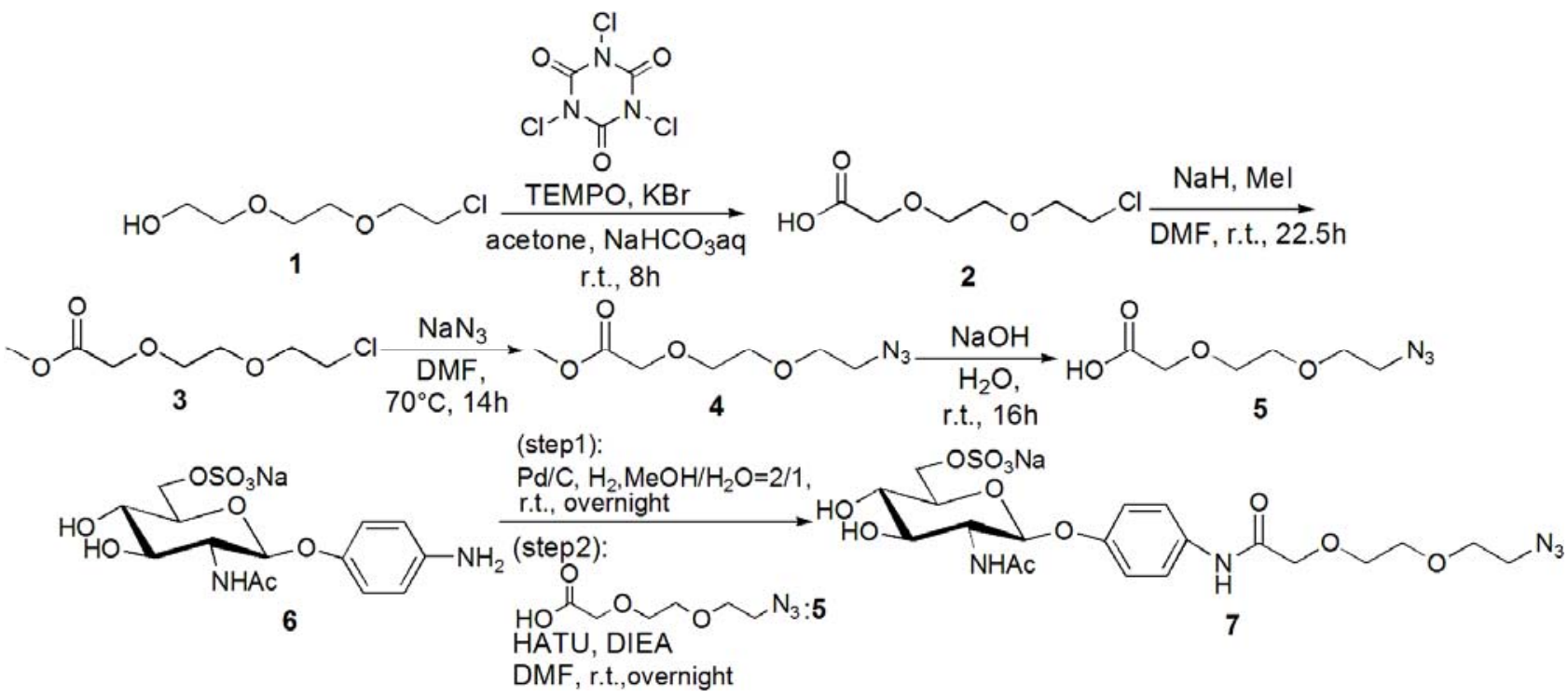

Scheme 2. Synthesis of 6-sulfo-GlcNAc trimer G0: 9.

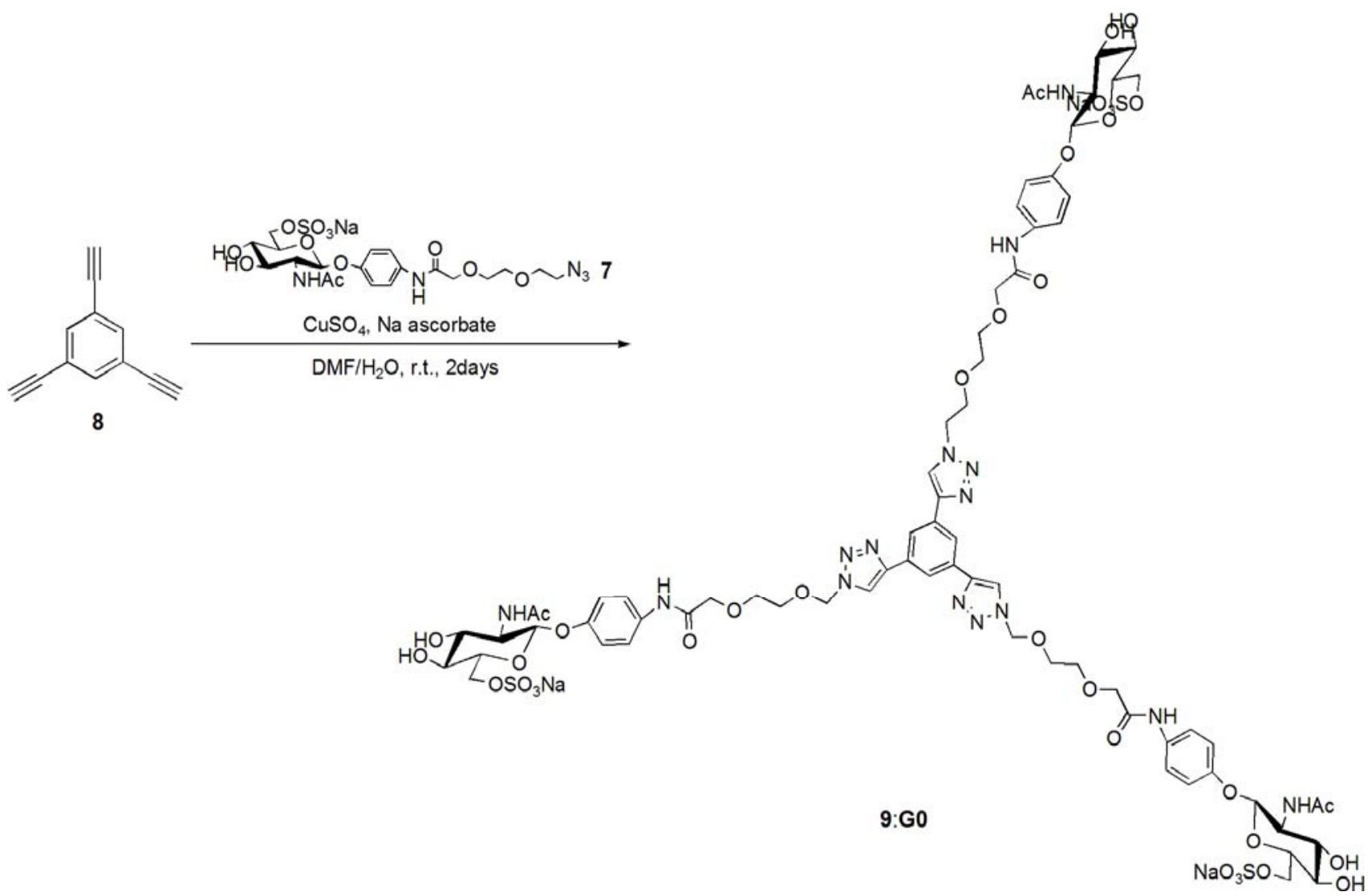

8 
Scheme 3. Synthesis of acetylene-terminated sulfonated GlcNAc 10.

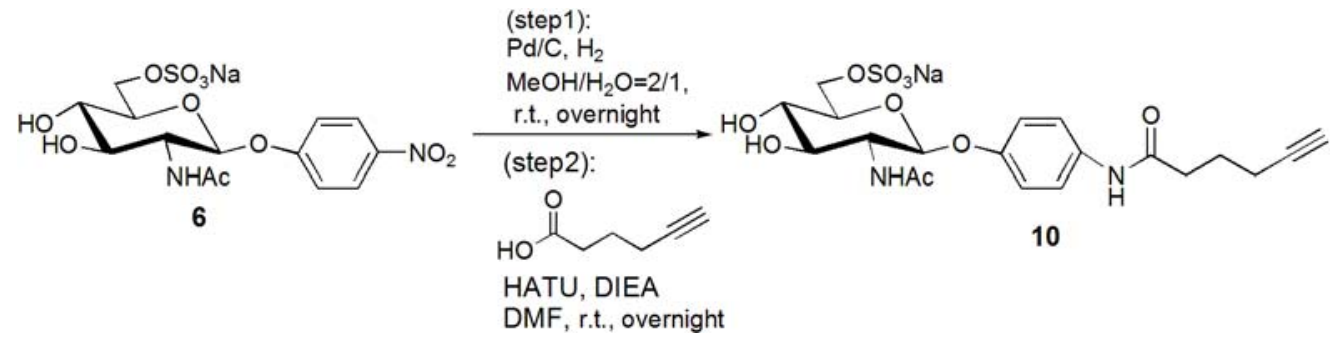

Scheme 4. Syntheses of the dendrimer core 15.

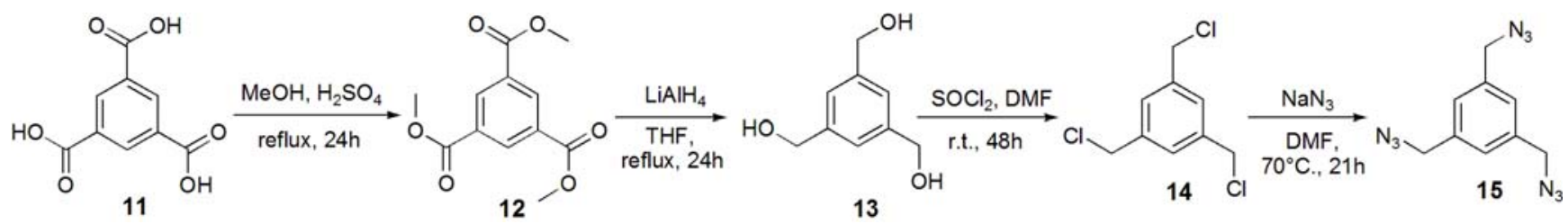

Scheme 5. Syntheses of the dendron 19.

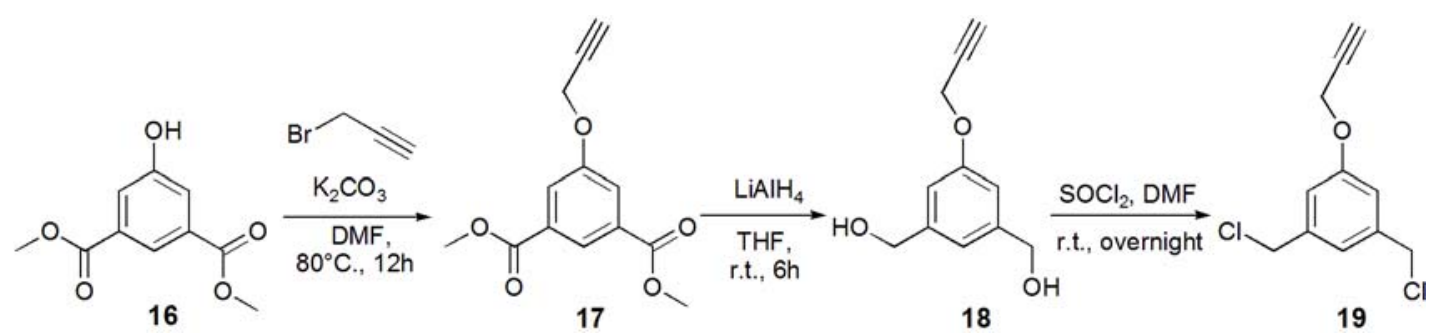

Scheme 6. Syntheses of 6-sulfo-GlcNAc hexamer G1: 22.

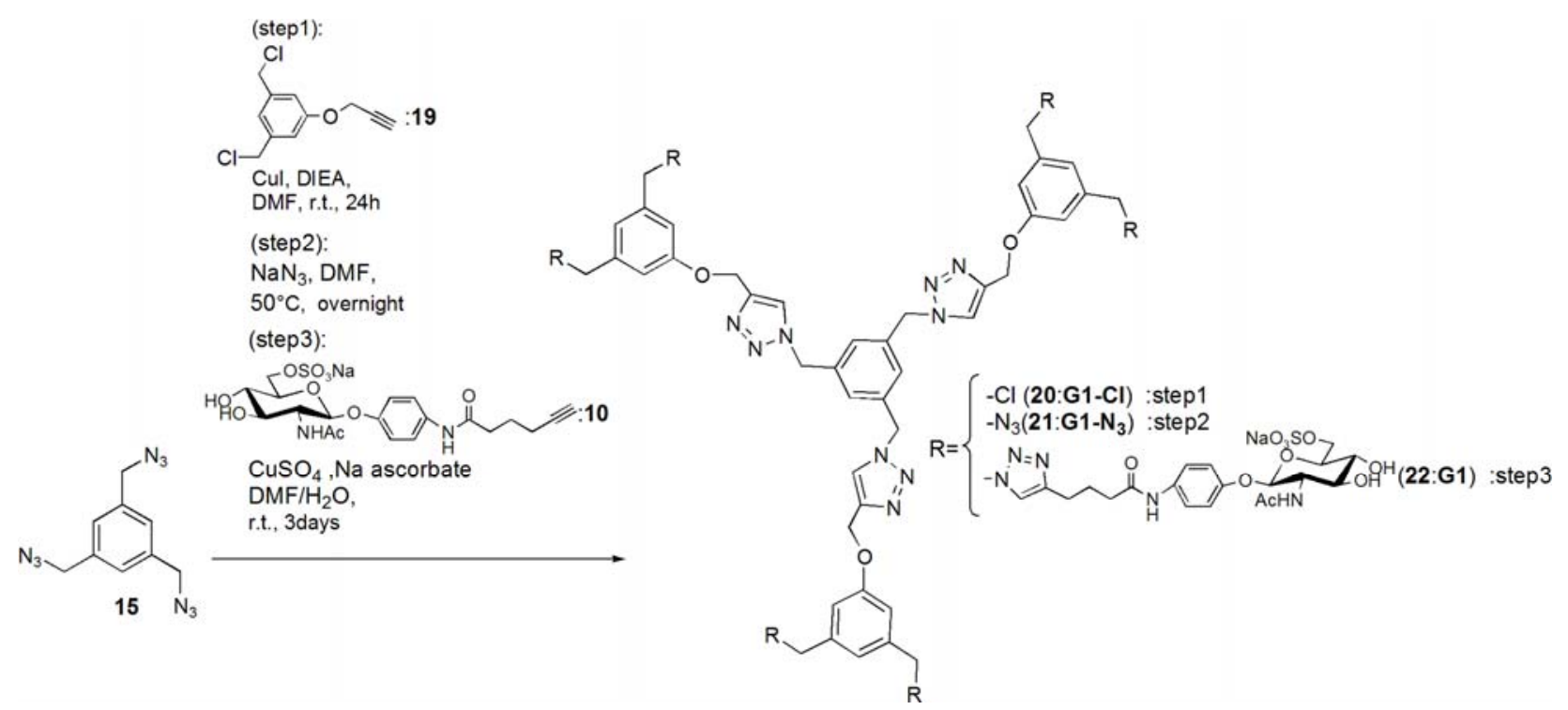


Scheme 7. Syntheses of 6-sulfo-GlcNAc dodecamer G2: 25.

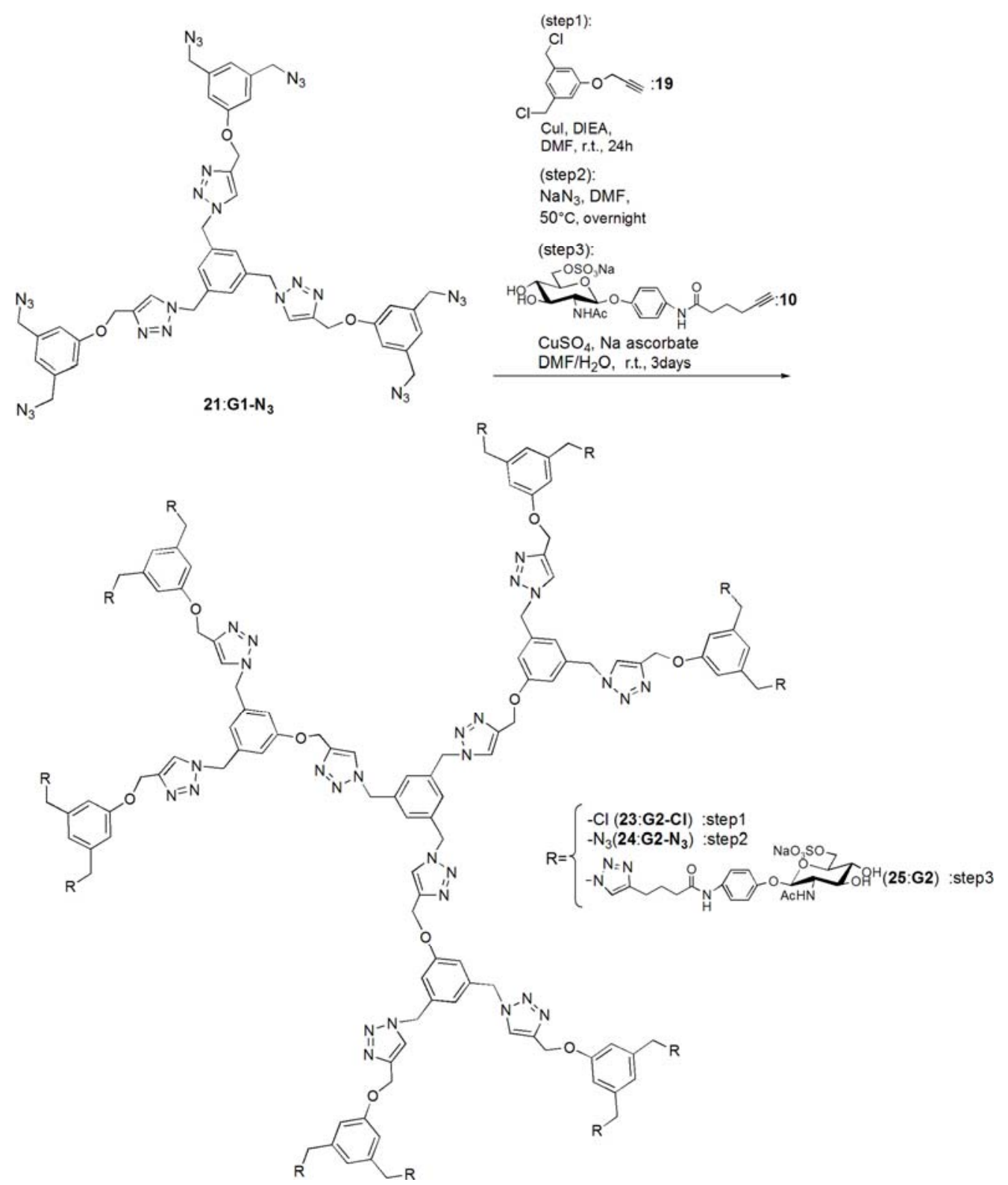

Glycodendrimers of $\mathbf{G 1}$ and G2 were obtained by click chemistry in a modest yield (G1: 28\%, G2: 21\%) (Schemes 6 and 7). 1,3,5-Tris(azidomethyl)benzene was used as the core of the dendrimer and was itself derived from 1,3,5-trimesic acid via sequential hydrogenation, chlorination and azidation reactions (Scheme 3). The structures of the compounds were confirmed by ${ }^{1} \mathrm{H}$ and ${ }^{13} \mathrm{C}-\mathrm{NMR}$, electrospray ionization mass spectroscopy (ESI-MS) and matrix-assisted laser desorption ionization and time of flight mass spectroscopy (MALDI-TOF-MS). Detailed syntheses and characterizations are provided in the Experimental Section.

\subsection{Lectin Recognition Ability}

Although the interaction mechanism of WGA is different from that of $A \beta$, the synthesized glycodendrimers were evaluated in a lectin recognition assay to estimate their biological ability (Figure 2) [19]. 
Figure 2. Fluorescence intensity changes of the FITC-WGA with varying sugar concentrations of the sulfonated GlcNAc derivatives.

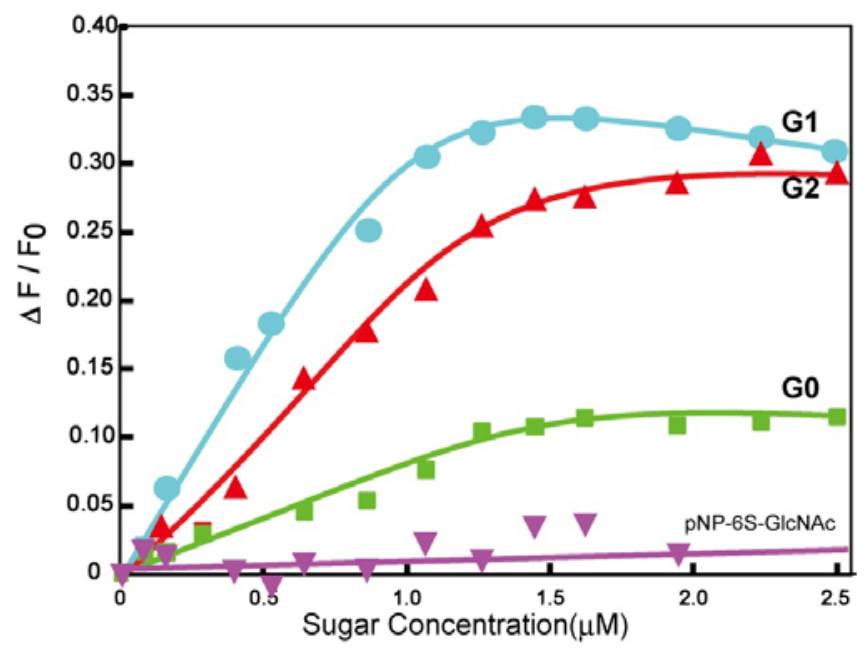

Fluorescence quenching of the fluorescein isothiocyanate (FITC)-WGA complex occurred upon the addition of the glycodendrimers [21]. The quenching behavior was analyzed using a Scatchard plot. The binding constants $\left(\mathrm{K}_{\mathrm{a}}\right)$ of G0, G1 and $\mathbf{G 2}$ were found to be $6.56 \times 10^{5}, 5.55 \times 10^{6}$ and $2.12 \times 10^{6}$ $\left(\mathrm{M}^{-1}\right)$, respectively, with the affinity constants therefore being of the order $\mathbf{G 1}>\mathbf{G 2}>>\mathbf{G 0}$. In contrast to WGA, the monomeric sulfonated GlcNAc did not show the same detectable affinity for lectin, and the addition of the glycodendrimers to FITC-bovine serum albumin did not induce fluorescence quenching. The results showed that the glycodendrimer of $\mathbf{G 1}$ and $\mathbf{G} 2$ had the ability to amplify the protein-saccharide interactions, indicating that the protein-saccharide interactions were specific to a certain extent. G0 did not show a high level of affinity for WGA, suggesting the potential for weak interactions to proteins including $A \beta$.

The hydrophobic domains of the dendrimes of G1 and G2 were analyzed by fluorescence of 8-anilino-1-naphthalene sulfonate (ANS) (Figure 3). The solution of G1 showed a larger blue shift in its emission spectra than that of G2, whereas the solution of G0 did not show any blue shift.

Figure 3. Fluorescence spectra of ANS $(20 \mu \mathrm{M})$ with sugar derivatives $(66.7 \mu \mathrm{M})$ in PBS buffer.

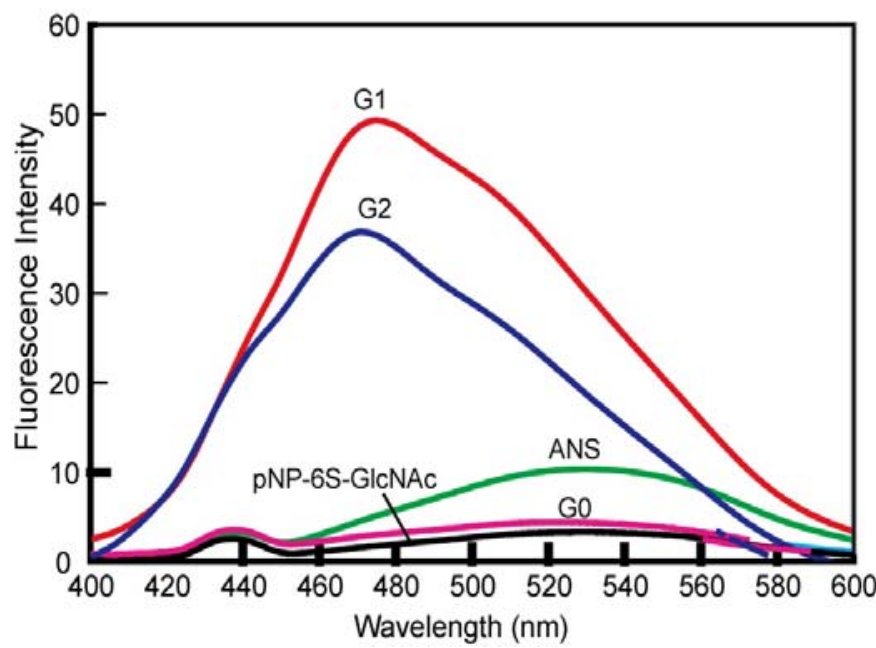


The hydrophobicity of dendrimer suggested that they would possess self-assembling properties in solution. Interestingly, the larger fluorescence of G1 versus that of G2 indicated the larger selfassembling properties of $\mathbf{G 1}$ in the aqueous solution. In addition, the glycodendrimers induced the formation of WGA aggregates. The diameters of WGA-glycodendrimer aggregates in the presence of WGA $(1.00 \mu \mathrm{M})$ were 752, 496 and $384 \mathrm{~nm}$, respectively, with G1, G2, and G0 (data not shown).

Multivalent GlcNAc generally showed a strong interaction based on the cluster glycoside effect [22], which was similar to the interaction observed for G1 and G2. The positive net charge of WGA also contributed to its interactions with $\mathbf{G 1}$ and $\mathbf{G 2}$ in an electrostatic manner. The sizes of the dendrimers by dynamic light scattering (DLS) became semi-micro in order in the presence of the WGA because of the cross-linking between the WGA and the dendrimer that occurred as a consequence of molecular recognition. The affinity of G1 was larger than that of G2, although the structure of G2 apparently exhibited a greater degree of multivalency. In addition, considering that the distance between the sugar binding sites was 1.5-5 $\mathrm{nm}$ in WGA [23,24], the sugar distance of G2 was better suited to accommodate WGA than that of G1. The affinities of dendrimers, however, showed an opposing trend. Taking the ANS results into account, G1 formed larger glycoside clusters than G2 through self-assembly, which resulted in the larger affinity for WGA. Given that the self-assembly plays an important role in the cluster glycoside effect of dendrimers, the affinity between WGA and dendrimer was considered to be dynamic including the cross linking and statistical re-binding aspects of the process. The results suggested that the glycodendrimers of G1 and G2 provided glycoside clusters suitable for binding WGA and $A \beta$.

\subsection{Inhibitory Effect of Glycodendrimer on Aß (1-42) Aggregation}

The interactions of the glycodendrimers with $A \beta$ were investigated. The aggregation properties of A $\beta$ (1-42) were analyzed by fluorescence spectroscopy with thioflavin T (ThT) [14,15]. It is known that ThT has an affinity for amyloid fibril and that the fluorescence of ThT increases when ThT is attached to amyloid fibrils. In the current experiment, the degree of amyloid formation was monitored by the fluorescence of ThT [25]. The level of amyloidosis was examined over an $8 \mathrm{~h}$ period and the fluorescence intensity following this period was evaluated as 1.0. The aggregation behaviors with various sugar additives are shown in Figure 4.

The monomeric 6-sulfonated GlcNAc did not exhibit an inhibitory effect on A $\beta$ aggregation, as we previously reported $[14,15]$. In contrast, the addition of sulfonated glycodendrimer modestly inhibited the aggregation of A $\beta$. The degree of inhibition was in the order $\mathbf{G 1}=\mathbf{G 2}>\mathbf{G 0}>>$ monomer. The addition of dendrimer inhibited the aggregation by approximately $50 \%$ relative to the level of inhibition observed in the absence of the additives.

The dendrimers of $\mathbf{G 1}$ and $\mathbf{G 2}$ were effective inhibitors of A $\beta$ aggregation, whereas the inhibitory effect of G0 was insufficient. The observed order of the inhibitory effect was similar to that observed for the lectin recognition. The results suggested that $\mathbf{G 1}$ and $\mathbf{G 2}$ displayed saccharides in a favorable manner for effective protein affinity. The molecular recognition of the saccharides by lectin was affected by the cluster glycoside effect, which was controlled by the spatial arrangement of the saccharides in the dendrimers or the self-assembled dendrimers. The appropriate glycoside clusters for WGA could also become a better inhibitor for Alzheimer amyloid aggregation. 
Figure 4. Time course of the fluorescence change in ThT with A $(1-42)(20 \mu \mathrm{M})$ and sugar derivatives $(200 \mu \mathrm{M})$ in the phosphate buffer.

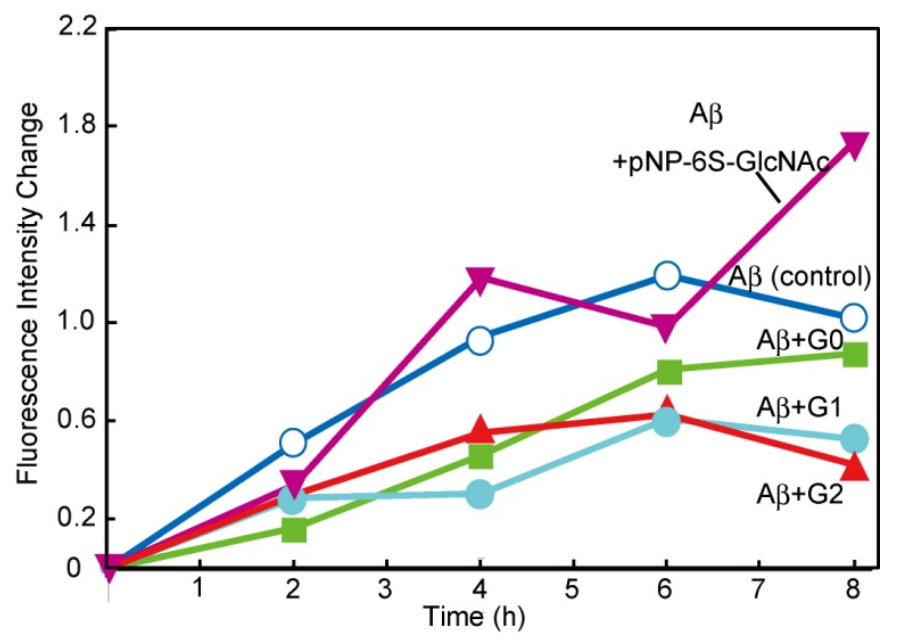

It has been reported that GAGs bind to $A \beta$ via electrostatic interactions with the basic segment 13HHQK16 [26]. Glycopolymers containing sulfonated saccharides were considered to interact with $\mathrm{A} \beta$ in the same way via electrostatic interactions [14,15]. Glycodendrimers are also considered to bind to $A \beta$ via the same electrostatic interactions. Although the glycodendrimer G1 showed the largest binding properties, its binding to $A \beta$ was almost identical to that of G2. Although the structures of WGA and $A \beta$ are totally different, it was considered that the larger cluster of the glycosides would show high levels of affinity that were similar to those observed in their interaction with WGA.

Multivalent sulfonated groups have been reported to interact with A $\beta$ with GAGs [26], 6-sulfoGlcNAc polymer [14,15], sulfonated Glc polymer [27], and the polymer with sulfonic acid [28]. It is obvious that the sulfonic acid interact with $A \beta$ via electrostatic interaction. The structural specificity and the mechanism of $A \beta$ interactions are under investigation in our group.

\subsection{Conformation Analysis of A $\beta$ with CD Spectra}

The conformation of $A \beta$ was investigated in the presence of the sulfonated glycodendrimer (Figure 5). In the absence of the sugar additives, $A \beta$ showed the negative cotton effect around $220 \mathrm{~nm}$, suggesting $\beta$-sheet conformation [29]. A $\beta$ also showed $\beta$-sheet structure in the presence of the monomeric sulfonated saccharide and G1. In contrast, the additions of G1 and G2 led to significant changes in the conformation, with the negative cotton effect observed around $220 \mathrm{~nm}$ almost disappearing entirely. The addition of G0 did not lead to a decrease in the negative cotton effect, suggesting that the interaction with $A \beta$ was weak.

$\mathrm{CD}$ spectra recorded in the presence of the sulfonated glycodendrimer indicated that its addition led to the inhibition of the aggregation and conformation change of $A \beta$. Since the amyloidosis relates to changes in the conformation and aggregation, these results were in good agreement with the Th- $T$ experiments. The inhibition of $A \beta$ aggregation was also evaluated with the sulfonated glycopolymer. The results revealed that the sulfonated glycoside clusters inhibited oligomer formation during the early stages of the amyloidosis. It was also considered that the sulfonated glycodendrimer interacted with $A \beta$ and inhibited the formation of the $A \beta$ oligomer [14]. 
Figure 5. CD spectra for $A \beta(1-42)(20 \mu \mathrm{M})$ in the presence of the sugar dendrimer additives $(200 \mu \mathrm{M})$ in the phosphate buffer.

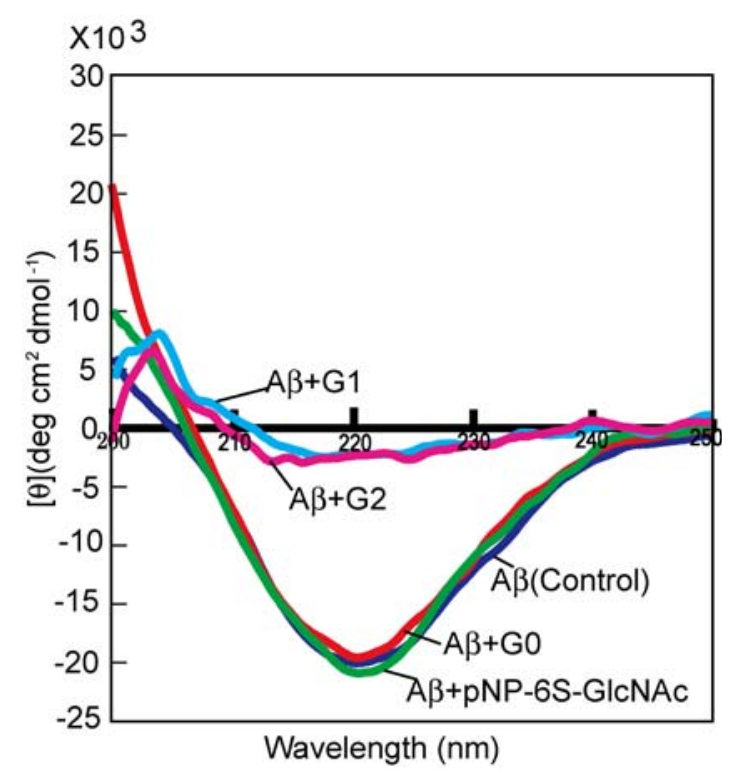

\subsection{Morphology Observation of $A \beta$}

To develop an understanding of the amyloidosis and the properties of the inhibitors, it was necessary to develop an understanding of the $A \beta$ morphology, because the results from the ThT fluorescence and CD spectra only provided an indirect reflection of the protein amyloidosis. The properties of the amyloid, including its cytotoxicity, were strongly related to the size and shape of the aggregates, and so the AFM measurements were indispensable in evaluating these properties [30]. A $\beta$ spontaneously formed nanofiber upon incubation, with widths of 45-70 nm and length of only a few micrometers (Figure 6a). A $\beta$ also formed nanofibers in the presence of the monomeric saccharide with widths of 35-70 nm, although the fibers were shorter in length at less than $1 \mu \mathrm{m}$ (Figure $6 \mathrm{~b}$ ). In contrast, the additions of $\mathbf{G 1}$ and $\mathbf{G 2}$ led to significant changes in the morphology of $A \beta$. Nanofibers of the $A \beta$ amyloid were not observed at all in the presence of $\mathbf{G 1}$ and $\mathbf{G 2}$ (Figure 6d,e). Interestingly, the addition of the sulfonated trimer of $\mathbf{G 0}$ induced the largest aggregates (Figure 6c).

The morphology of $A \beta$ correlated well with the results of the ThT and CD analyses. $A \beta$ formed nanofibers in the absence of any additives. AFM analysis revealed that the monomeric 6-sulfonated GlcNAc showed the lowest level of $A \beta$ aggregation inhibition, and this result was consistent with the results of the ThT fluorescence and CD spectra. In contrast, the AFM results indicated that the dendrimers of $\mathbf{G 1}$ and $\mathbf{G 2}$ showed the highest levels of $A \beta$ aggregation inhibition, which were in good agreement with the results of the ThT and CD spectra. The formation of large aggregates was inhibited by the strong interaction with the glycodendrimer.

For G0 (trimer of 6-sulfonated GlcNAc), the AFM results indicated that the material only exerted a minor impact on the inhibition of $A \beta$ aggregation, with the result being consistent with the ThT and $\mathrm{CD}$ results. Furthermore, the aggregates in this case were much larger than those formed in the absence of the additives. The shape of the aggregates was different from the nanofiber of the amyloid. The morphology of G0 was measured in the absence of $A \beta$ and the results indicated that $\mathbf{G 0}$ formed small aggregates (Figure 7) even though the hydrophobicity by ANS fluorescence was small. 
Figure 6. AFM observations of $A \beta(1-42)(20 \mu \mathrm{M})(\mathbf{a})$ in the absence of an additive, (b) in the presence of pNP-6S-GlcNAc $(200 \mu \mathrm{M}),(\mathbf{c})$ in the presence of G0 $(200 \mu \mathrm{M}),(\mathbf{d})$ in the presence of G1 $(200 \mu \mathrm{M})$, and (e) in the presence of G2 $(200 \mu \mathrm{M})$.
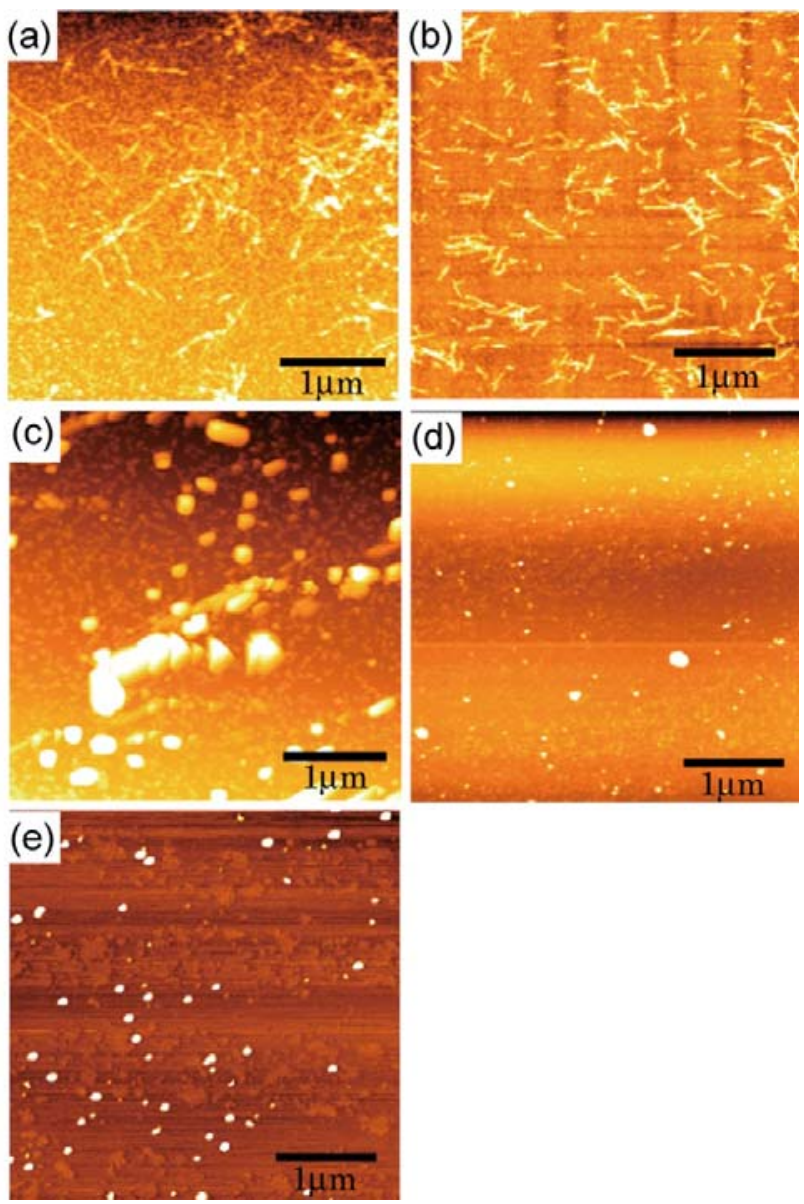

Figure 7. AFM observation of G0 $(200 \mu \mathrm{M})$.

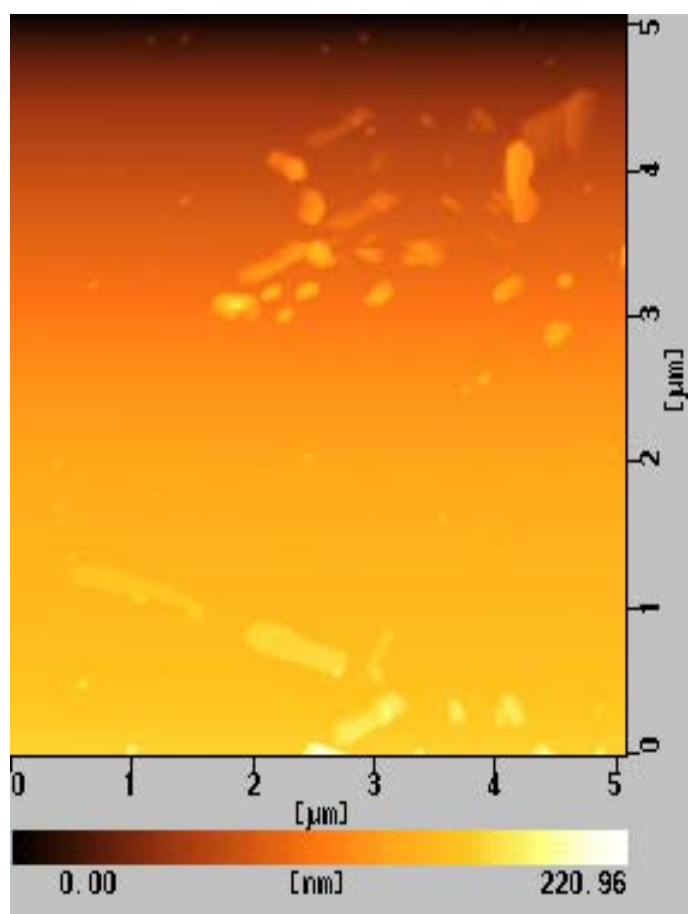


The morphology of Figure 6c was considered to be representative of a mixture of $A \beta$ and G0 aggregates. Since the interaction of $A \beta$ with $\mathbf{G 0}$ was weaker than its interactions with $\mathbf{G 1}$ and $\mathbf{G 2}$, the nanofiber formation of $A \beta$ aggregates was not hindered. G0 was envisaged to have behaved as a glue, effectively bringing $A \beta$ units together to yield the observed large objects. The morphology in this particular experiment was determined to be mixture of $A \beta, A \beta$-dendrimer and dendrimer aggregates. In spite of this, it was expected that the cytotoxicity of $A \beta$ would be reduced by the addition of G0 because of the resulting reduction in the number of toxic $A \beta$ aggregates.

\section{Experimental}

\subsection{Materials}

The following reagents were used as received: $N$-acetylglucosamine, copper(0) powder, copper(II) sulfate, copper(I)iodide, $N, N$-dimethylformamide (DMF), chloroform $\left(\mathrm{CHCl}_{3}\right)$, ethyl acetate (EtOAc), $n$-hexane, magnesium sulfate $\left(\mathrm{MgSO}_{4}\right)$, methanol $(\mathrm{MeOH})$, methylene chloride $\left(\mathrm{CH}_{2} \mathrm{Cl}_{2}\right)$, potassium bromide $(\mathrm{KBr})$, potassium carbonate $\left(\mathrm{K}_{2} \mathrm{CO}_{3}\right)$, 2-propanol, sodium L-ascorbate, sodium azide $\left(\mathrm{NaN}_{3}\right)$, sodium bicarbonate $\left(\mathrm{NaHCO}_{3}\right)$, sodium carbonate $\left(\mathrm{Na}_{2} \mathrm{CO}_{3}\right)$ sodium hydride $(\mathrm{NaH})$, sodium hydroxide $(\mathrm{NaOH})$, tetrahydrofuran (THF), thioflavin-T(ThT), thionyl chloride $\left(\mathrm{SOCl}_{2}\right)$, (Kanto Chemical Co., Inc., Tokyo, Japan), 2-[2-(2-chloroethoxy)ethoxy]ethanol, DIEA, 5-hexynoic acid, propargyl bromide, 2,2,6,6-tetramethylpiperidine 1-oxyl (TEMPO), trichloroisocyanuric acid, 1,3,5-triethynylbenzene, trimesic acid (TCI Co., Tokyo, Japan), amyloid $\beta$ protein (human, 1-42) (A $\beta$ (1-42)), HATU (Peptide Institute Inc., Osaka, Japan), palladium/charcoal (Pd/C) (Merck \& Co., Inc., Whitehouse Station, NJ, USA), and deuterated solvents $\left(\mathrm{CDCl}_{3}, \mathrm{CD}_{3} \mathrm{OD}, \mathrm{DMF}-d_{7}\right.$ and $\left.\mathrm{D}_{2} \mathrm{O}\right)$, dimethyl 5-hydroxyisophtalate, and lithium alminium hydride $\left(\mathrm{LiAlH}_{4}\right)$ (Sigma-Aldrich, St. Louis, MO, USA). 6-sodium sulfo- $N$ acetyl- $\beta$-D-glucosamine (6) was synthesized according to the previous literature $[5,14]$.

\subsection{Measurements}

The identities of the compounds were confirmed by the following methods. Both ${ }^{1} \mathrm{H}-\mathrm{NMR}(300 \mathrm{MHz})$ and ${ }^{13} \mathrm{C}$-NMR (75 MHz) spectra were recorded using a Varian Gemini 2000 spectrometer and ${ }^{1} \mathrm{H}-\mathrm{NMR}$ (500 MHz) spectra was recorded using a Varian UNITY 500plus spectrometer, equipped with a Sun workstation, respectively. The spectra were measured in $\mathrm{CDCl}_{3}, \mathrm{CD}_{3} \mathrm{OD}, \mathrm{DMF}-\mathrm{d}_{7}$ and $\mathrm{D}_{2} \mathrm{O}$ solvents at room temperature. Mass spectra were measured on a MALDI-TOF-MS (Voyager, Applied Biosystems, Foster City, CA, USA) and ESI-MS (LCQ Deca xp, Thermo Fisher Scientific, Waltham, MA, USA). CD spectra were recorded using a JASCO J-720 spectrometer (JASCO, Tokyo, Japan). AFM measurement was carried out using SPA400 instrument (Seiko Instruments Inc., Tokyo, Japan) with a $40 \mathrm{~N}$ cantilever. Fluorescence spectra were measured on a JASCO FP-6500 (JASCO) at $25{ }^{\circ} \mathrm{C}$. DLS for the GNPs was determined using a Zetasizer 3000 (Sysmex, Kobe, Japan).

\subsection{Syntheses}

[2-(2-Chloroethoxy)ethoxy] acetic acid (2). [2-(2-Chloroethoxy)ethoxy]ethanol (1, $2.20 \mathrm{~g}, 13.0 \mathrm{mmol})$ was dissolved in acetone $(30 \mathrm{~mL})$, and $15 \% \mathrm{NaHCO}_{3}$ aq. was added to the solution at $0{ }^{\circ} \mathrm{C} . \mathrm{KBr}(0.312 \mathrm{~g}$, $2.60 \mathrm{mmol})$ and TEMPO $(0.040 \mathrm{~g}, 0.040 \mathrm{mmol})$ were added to the solution, and trichloroisocyanuric 
acid $(6.10 \mathrm{~g}, 26.2 \mathrm{mmol})$ was added dropwise. The solution was allowed to warm up to room temperature, and stirred for $8 \mathrm{~h}$. The reaction was confirmed by TLC (EtOAc- $n$-hexane $=3: 1$ ), and 2-propanol $(10 \mathrm{~mL})$ was added to quench the reaction. The reaction mixture was filtrated with Celite, and neutralized with sat. $\mathrm{Na}_{2} \mathrm{CO}_{3}$ aq. The solution was acidified with $1 \mathrm{~N} \mathrm{HCl}$, and extracted with $\mathrm{CHCl}_{3}$. The organic phase was dried over $\mathrm{MgSO}_{4}$, and $\mathrm{MgSO}_{4}$ was removed by filtration. The solution was evaporated to yield yellow oil; Yield $1.94 \mathrm{~g}, 88.6 \%$. ${ }^{1} \mathrm{H}-\mathrm{NMR}\left(300 \mathrm{MHz}\right.$, r.t., $\mathrm{CDCl}_{3}$ ): $\delta / \mathrm{ppm}$ 3.58-3.60 (m, 2H, CH$), 3.64-3.68\left(\mathrm{~m}, 2 \mathrm{H}, \mathrm{CH}_{2}\right), 3.69-3.70\left(\mathrm{~m}, 2 \mathrm{H}, \mathrm{CH}_{2}\right), 3.71-3.76\left(\mathrm{~m}, 2 \mathrm{H}, \mathrm{CH}_{2}\right)$, $4.18\left(\mathrm{~s}, 2 \mathrm{H}, \mathrm{CH}_{2}\right)$. IR wavenumber $\left[\mathrm{cm}^{-1}\right]$ : $3470(\mathrm{OH}) 1734(\mathrm{C}=\mathrm{O}) 1112(\mathrm{C}-\mathrm{O})$. ESI-MS (negative): $181.2[\mathrm{M}-\mathrm{H}]^{-}$.

Methyl 2-[2-(2-chloroethoxy)ethoxy] acetate (3). Compound 2 (0.312 g, $1.78 \mathrm{mmol})$ was dissolved in DMF $(2 \mathrm{~mL})$, and $\mathrm{NaH}(0.530 \mathrm{~g}, 2.22 \mathrm{mmol})$ was added to the solution at $0{ }^{\circ} \mathrm{C}$. After stirring for $30 \mathrm{~min}$, MeI $(0.649 \mathrm{~g}, 3.33 \mathrm{mmol})$ was added to the solution. The reaction mixture was stirred for $22.5 \mathrm{~h}$ at room temperature. The reaction was confirmed by TLC (EtOAc- $n$-hexane $=1: 3$ ). The solution was evaporated, and the residue was dissolved in $\mathrm{CHCl}_{3}$. The solution was washed with $1 \mathrm{~N} \mathrm{HCl}$, sat. $\mathrm{NaHCO}_{3}$ aq. and brine. The solution was dried over $\mathrm{MgSO}_{4}$, and $\mathrm{MgSO}_{4}$ was removed by filtration. The residue was purified by column chromatography (EtOAc- $n$-hexane $=1: 3$ ) to yield colorless oil; Yield 0.242 g, 74.4\%. ${ }^{1} \mathrm{H}-\mathrm{NMR}\left(300 \mathrm{MHz}\right.$, r.t., $\mathrm{CDCl}_{3}$ ): $\delta / \mathrm{ppm} 3.62$ (t, $2 \mathrm{H}, J=6 \mathrm{~Hz}, J=6 \mathrm{~Hz}, \mathrm{CH}_{2}$ ), 3.71-3.72 (m, 2H, CH$), 3.72-3.74\left(\mathrm{~m}, 2 \mathrm{H}, \mathrm{CH}_{2}\right), 3.73\left(\mathrm{~s}, 3 \mathrm{H}, \mathrm{CH}_{3}\right), 3.74-3.76\left(\mathrm{~m}, 2 \mathrm{H}, \mathrm{CH}_{2}\right), 4.16$ (s, $2 \mathrm{H}, \mathrm{CH}_{2}$ ). ESI-MS (positive): $219.1[\mathrm{M}+\mathrm{Na}]^{+}$.

Methyl 2-[2-(2-azidoethoxy)ethoxy]acetate (4). Compound 3 (0.242 g, $1.31 \mathrm{mmol})$ was dissolved in DMF $(15 \mathrm{~mL}) . \mathrm{NaN}_{3}(0.511 \mathrm{~g}, 7.86 \mathrm{mmol})$ was added to the solution, and stirred for $14 \mathrm{~h}$ at $70{ }^{\circ} \mathrm{C}$. The reaction was confirmed by TLC (EtOAc- $n$-hexane $=1: 3) . \mathrm{NaN}_{3}$ was removed by filtration, and the solution was evaporated. The residue was dissolved in $\mathrm{CHCl}_{3}$, and the solution was washed with $1 \mathrm{~N}$ $\mathrm{HCl}$, sat. $\mathrm{NaHCO}_{3}$ aq. and brine. The organic phase was dried over $\mathrm{MgSO}_{4}$, and $\mathrm{MgSO}_{4}$ was removed by filtration. The solution was evaporated to yield colorless oil; Yield $0.220 \mathrm{~g}, 87.8 \%$. ${ }^{1} \mathrm{H}-\mathrm{NMR}$ (300 MHz, r.t., $\mathrm{CDCl}_{3}$ ): $\delta / \mathrm{ppm} 3.38$ (t, $\left.2 \mathrm{H}, J=5 \mathrm{~Hz}, J=5 \mathrm{~Hz}, \mathrm{CH}_{2}\right), 3.65-3.67\left(\mathrm{~m}, 2 \mathrm{H}, \mathrm{CH}_{2}\right.$ ), 3.67-3.67 (m, 2H, $\left.\mathrm{CH}_{2}\right), 3.70-3.72\left(\mathrm{~m}, 2 \mathrm{H}, \mathrm{CH}_{2}\right), 3.73\left(\mathrm{~s}, 3 \mathrm{H}, \mathrm{CH}_{3}\right), 4.16\left(\mathrm{~s}, 2 \mathrm{H}, \mathrm{CH}_{2}\right)$. ESI-MS (positive) $226.1[\mathrm{M}+\mathrm{Na}]^{+}$.

[2-(2-Azidoethoxy)ethoxy]acetic acid (5). Compound $4(0.220 \mathrm{~g}, 1.15 \mathrm{mmol})$ was dissolved in $1 \mathrm{~N}$ $\mathrm{NaOHaq}(15 \mathrm{~mL})$, and the solution was stirred for $16 \mathrm{~h}$. The reaction was confirmed by TLC $\left(\right.$ EtOAc- $n$-hexane $=1: 3$ ). The solution was acidified with $1 \mathrm{~N} \mathrm{HCl}$, and extracted with $\mathrm{CHCl}_{3}$. The solution was dried over $\mathrm{MgSO}_{4}$, and $\mathrm{MgSO}_{4}$ was removed by filtration. The solution was evaporated to yield colorless oil; Yield 0.172g, 84.4\%. ${ }^{1} \mathrm{H}-\mathrm{NMR}\left(300 \mathrm{MHz}\right.$, r.t., $\left.\mathrm{CDCl}_{3}\right): \delta / \mathrm{ppm} 3.41$ (t, 2H, J=4.8 Hz, $\left.J=5.1 \mathrm{~Hz}, \mathrm{CH}_{2}\right), 3.67-3.69\left(\mathrm{~m}, 2 \mathrm{H}, \mathrm{CH}_{2}\right), 3.70-3.71\left(\mathrm{~m}, 2 \mathrm{H}, \mathrm{CH}_{2}\right), 3.75-3.78\left(\mathrm{~m}, 2 \mathrm{H}, \mathrm{CH}_{2}\right), 4.16$ (s, $2 \mathrm{H}, \mathrm{CH}_{2}$ ). ESI-MS (negative): $188.6[\mathrm{M}-\mathrm{H}]^{-}$.

$p$-N-[2-(2-Azidoethoxy)ethoxy] amidophenyl-2-acetamido-2-deoxy-6-sulfo- $\beta$-D-glucopyranoside

Compound 6 was synthesized by following the previous method [5,14]. Next 6 (0.142 g, $0.320 \mathrm{mmol})$ was dissolved in $\mathrm{MeOH}-\mathrm{H}_{2} \mathrm{O}=2: 1(10 \mathrm{~mL}) . \mathrm{Pd} / \mathrm{C}(20 \mathrm{mg})$ was added to the solution, and the solution was stirred overnight under $\mathrm{H}_{2} . \mathrm{Pd} / \mathrm{C}$ was removed by filtration, and the solution was evaporated. The 
residue was dissolved in DMF $(5 \mathrm{~mL})$, and $5(86.2 \mathrm{mg}, 0.456 \mathrm{mmol})$ was added to the solution. HATU (185 mg, $0.487 \mathrm{mmol}$ ) and DIEA $(83 \mu \mathrm{L}, 0.487 \mathrm{mmol})$ were added to the solution, and the solution was stirred overnight. The solution was evaporated, and the residue was purified by column chromatography $\left(\mathrm{H}_{2} \mathrm{O}-\mathrm{MeOH}=5: 1\right)$ to yield a brown solid; Yield 0.160 g, 83.2\%. ${ }^{1} \mathrm{H}-\mathrm{NMR}\left(500 \mathrm{MHz}\right.$, r.t., $\left.\mathrm{D}_{2} \mathrm{O}\right): \delta / \mathrm{ppm}$ $2.09\left(\mathrm{~s}, 3 \mathrm{H}, \mathrm{OCOC}_{3}\right), 3.36-3.39\left(\mathrm{~m}, 2 \mathrm{H}, \mathrm{CH}_{2}\right), 3.48\left(\mathrm{t}, 1 \mathrm{H}, J_{\mathrm{H} 3-\mathrm{H} 4}=9.0 \mathrm{~Hz}, J_{\mathrm{H} 4-\mathrm{H} 5}=9.5 \mathrm{~Hz}, \mathrm{H} 4\right), 3.54(\mathrm{t}$, $\left.1 \mathrm{H}, J_{\mathrm{H} 2-\mathrm{H} 3}=10.0 \mathrm{~Hz}, J_{\mathrm{H} 3-\mathrm{H} 4}=9.5 \mathrm{~Hz}, \mathrm{H} 3\right), 3.57-3.62\left(\mathrm{~m}, 2 \mathrm{H}, \mathrm{CH}_{2}\right), 3.66-3.68\left(\mathrm{~m}, 2 \mathrm{H}, \mathrm{CH}_{2}\right), 3.71-3.73$ $\left(\mathrm{m}, 2 \mathrm{H}, \mathrm{CH}_{2}\right), 3.74-3.75(\mathrm{~m}, 1 \mathrm{H}, \mathrm{H} 5), 3.88\left(\mathrm{t}, 1 \mathrm{H}, J_{\mathrm{H} 1-\mathrm{H} 2}=9.5 \mathrm{~Hz}, J_{\mathrm{H} 2-\mathrm{H} 3}=9.5 \mathrm{~Hz}, \mathrm{H} 2\right), 4.11(\mathrm{~s}, 2 \mathrm{H}$, $\left.\mathrm{CH}_{2}\right), 4.13\left(\mathrm{dd}, 1 \mathrm{H}, J_{\mathrm{H} 5-\mathrm{H} 6 \text { proR }}=4.0 \mathrm{~Hz}, J_{\mathrm{H} 6 \text { proR-H6proS }}=6.0 \mathrm{~Hz}, \mathrm{H} 6\right.$ proR$), 4.28(\mathrm{~d}, 1 \mathrm{H}, J=10 \mathrm{~Hz}$ H6proS), 5.01 (d, $J=8.5 \mathrm{~Hz}, \mathrm{H1}), 6.98\left(\mathrm{~d}, 2 \mathrm{H}, J_{\mathrm{o}-\mathrm{m}}=7.0 \mathrm{~Hz}, \mathrm{Ph}-\mathrm{o}\right), 7.27$ (d, 2H, $\left.J_{\mathrm{o}-\mathrm{m}}=9.0 \mathrm{~Hz}, \mathrm{Ph}-\mathrm{m}\right)$. ESI-MS (negative): $421.1[\mathrm{M}-\mathrm{Na}]^{-}$.

pNP 6-Sulfo-GlcNAc trimer (G0:9). Compound 7 (91.8 mg, $0.157 \mathrm{mmol})$ and 1,3,5-triethylbenzene (8) $(5.12 \mathrm{mg}, 0.0341 \mathrm{mmol})$ were dissolved in DMF $(20 \mathrm{~mL})$. To the solution, sodium ascorbate $(12.2 \mathrm{mg}$, 0.6 eq.) and $\mathrm{CuSO}_{4}$ (4.91 mg, 0.3 eq.) was added. The solution was stirred for 2 days, and the reaction was confirmed by reversed phase TLC $\left(\mathrm{H}_{2} \mathrm{O}-\mathrm{MeOH}=5: 1\right)$. Copper was removed by centrifugation, and the residue was purified by column chromatography $\left(\mathrm{H}_{2} \mathrm{O}-\mathrm{MeOH}=5: 1\right)$ to yield colorless solid; Yield 0.0320g, 49.2\%. ${ }^{1} \mathrm{H}-\mathrm{NMR}\left(300 \mathrm{MHz}\right.$, r.t., $\mathrm{D}_{2} \mathrm{O}$ ): $\delta / \mathrm{ppm} 1.86\left(\mathrm{~s}, 9 \mathrm{H}, \mathrm{CH}_{3}\right.$ ), 3.41-3.47 (overlap, 6H, $\mathrm{CH}_{2}$ ), 3.41-3.47 (overlap, 3H, H4), 3.52-3.57 (overlap, 3H, H3), 3.52-3.57 (overlap, 12H, $\mathrm{CH}_{2} \times 2$ ), 3.66 (broad, 3H, 5H), 3.66 (broad, 6H, $\mathrm{CH}_{2}$ ), 3.75-3.77 (overlap, 3H, H2), 3.77 (s, 6H, $\mathrm{CH}_{2}$ ), 3.98 (s, 6H, NH), 4.05-4.07 (m, 3H, H6proR), 4.16 (d, 3H, $J=11.5$ Hz H6proS), 4.61-4.62 (overlap, 3H, H1), $6.47\left(\mathrm{~d}, 6 \mathrm{H}, J_{\mathrm{o}-\mathrm{m}}=9.0 \mathrm{~Hz}, \mathrm{Ph}-\mathrm{o}\right), 6.77\left(\mathrm{~d}, 6 \mathrm{H}, J_{\mathrm{o}-\mathrm{m}}=8.5 \mathrm{~Hz}, \mathrm{Ph}-\mathrm{m}\right), 7.53$ (s, 3H, Ar), $8.18(\mathrm{~s}, 3 \mathrm{H}$, $\mathrm{C}=\mathrm{CH}) .{ }^{13} \mathrm{C}-\mathrm{NMR}\left(75 \mathrm{MHz}\right.$, r.t., $\left.\mathrm{D}_{2} \mathrm{O}\right): \delta / \mathrm{ppm} 21.6,49.5,53.7,54.8,66.2,67.8,68.7,68.8,69.2,72.9$, $73.3,99.3,116.1,121.2,121.7,122.6,130.0,130.6,153.2,169.2,174.0$. ESI-MS: $\mathrm{m} / z \quad 976.1$ $[\mathrm{M}+2 \mathrm{Na}]^{2+}$, (LCMS, negative) $m / z 822.9[\mathrm{M}-3 \mathrm{Na}]^{3-}$.

p-N-(5-Hexynoic)amidophenyl-2-acetoamido-2-deoxy-6-sulfo- $\beta$-D-glucopyranoside (10). Compound 6 was dissolved in $\mathrm{MeOH}-\mathrm{H}_{2} \mathrm{O}=2: 1 . \mathrm{Pd} / \mathrm{C}$ was added to the solution, and the solution was stirred overnight under $\mathrm{H}_{2} . \mathrm{Pd} / \mathrm{C}$ was removed by filtration, and the solution was evaporated. The residue, $p$-aminophenyl-2-acetoamido-2-deoxy-6-sulfo- $\beta$-D-glucopyranoside $(0.353 \mathrm{~g}, 0.853 \mathrm{mmol})$ was dissolved in DMF $(20 \mathrm{~mL})$, and 5-hexynoic acid $(0.143 \mathrm{~g}, 1.28 \mathrm{mmol})$ was added to the solution at $0{ }^{\circ} \mathrm{C}$. HATU $(0.486 \mathrm{~g}, 1.28 \mathrm{mmol})$ and DIEA $(217 \mu \mathrm{L}, 1.28 \mathrm{mmol})$ was added to the solution, and the solution was stirred overnight. DMF was evaporated, and the residue was purified by reversed phase column chromatography $\left(\mathrm{H}_{2} \mathrm{O}-\mathrm{MeOH}=\right.$ from 5:1 to 2:1) to yield white solid; Yield $0.366 \mathrm{~g}, 81.6 \%$. ${ }^{1} \mathrm{H}-\mathrm{NMR}$ (500 MHz, r.t., $\mathrm{D}_{2} \mathrm{O}$ ): $\delta / \mathrm{ppm} 1.74\left(\mathrm{t}, J=7.0 \mathrm{~Hz}, 2 \mathrm{H}, \mathrm{CH}_{2}\right), 1.90\left(\mathrm{~s}, 3 \mathrm{H}, \mathrm{OCOC}_{3}\right), 2.15-2.18(\mathrm{~m}, 2 \mathrm{H}$, $\left.\mathrm{CH}_{2}\right), 2.25(\mathrm{t}, J=2.5 \mathrm{~Hz}, 1 \mathrm{H}, \mathrm{C} \equiv \mathrm{CH}), 2.36-2.39\left(\mathrm{~m}, 2 \mathrm{H}, \mathrm{CH}_{2}\right), 3.47\left(\mathrm{t}, 1 \mathrm{H}, J_{\mathrm{H} 3-\mathrm{H} 4}=9.5 \mathrm{~Hz}, J_{\mathrm{H} 4-\mathrm{H} 5}=9.5 \mathrm{~Hz}\right.$, $\mathrm{H} 4), 3.52-3.55(\mathrm{~m}, 1 \mathrm{H}, \mathrm{H} 3), 3.70-3.73(\mathrm{~m}, 1 \mathrm{H}, \mathrm{H} 5), 3.87\left(\mathrm{t}, 1 \mathrm{H}, J_{\mathrm{H} 1-\mathrm{H} 2}=8.5 \mathrm{~Hz}, J_{\mathrm{H} 2-\mathrm{H} 3}=10 \mathrm{~Hz}, \mathrm{H} 2\right), 4.11$ $\left(\mathrm{dd}, 1 \mathrm{H}, J_{\mathrm{H} 5-\mathrm{H} 6 \mathrm{proR}}=5.5 \mathrm{~Hz}, J_{\mathrm{H} 6 \mathrm{proR}-\mathrm{H} 6 \mathrm{proS}}=5.0 \mathrm{~Hz}, \mathrm{H} 6 \mathrm{proR}\right), 4.25(\mathrm{~d}, 1 \mathrm{H}, J=11.5 \mathrm{~Hz}, \mathrm{H} 6 \mathrm{proS}), 4.99$ (d, $J=8.5 \mathrm{~Hz}, \mathrm{H1}), 6.93$ (d, 2H, $\left.J_{\mathrm{o}-\mathrm{m}}=9.5 \mathrm{~Hz}, \mathrm{Ph}-\mathrm{o}\right), 7.27$ (d, 2H, $\left.J_{\mathrm{o}-\mathrm{m}}=9.5 \mathrm{~Hz}, \mathrm{Ph}-\mathrm{m}\right)$.

Trimethyl 1,3,5-benzenetricarboxylate (12). Trimesic acid (11, $8.00 \mathrm{~g}, 38.1 \mathrm{mmol})$ was dissolved in $\mathrm{MeOH}(140 \mathrm{~mL})$, and conc. $\mathrm{H}_{2} \mathrm{SO}_{4}(2 \mathrm{~mL})$ was added to the reaction mixture. The solution was refluxed for $24 \mathrm{~h}$, and the solution was evaporated. The residue was dissolved in $\mathrm{CHCl}_{3}$, and washed 
with sat. $\mathrm{Na}_{2} \mathrm{CO}_{3}$ aq. The solution was dried with $\mathrm{MgSO}_{4}$, and removed by filtration. The solution was evaporated to obtain white solid; Yield $9.09 \mathrm{~g}, 94.7 \%$. ${ }^{1} \mathrm{H}-\mathrm{NMR}\left(300 \mathrm{MHz}\right.$, r.t., $\left.\mathrm{CDCl}_{3}\right)$ : $\delta / \mathrm{ppm} 3.96$ (s, 9H, OMe), 8.83 (s, 3H, Ar).

1,3,5-Trihydroxymethylbenzene (13). Compound 12 (1.00 g, $3.97 \mathrm{mmol})$ was dissolved in THF (70 mL). $\mathrm{LiAlH}_{4}(35.7 \mathrm{mmol})$ was added to the solution, and the solution was refluxed for $24 \mathrm{~h}$. The reaction was confirmed by TLC (EtOAc- $n$-hexane $=1: 1$ ), and water was added to the reaction in order to quench the reaction. The solution was dried over $\mathrm{MgSO}_{4}$ and evaporated to yield white solid; Yield 0.571 g, 85.6\%. ${ }^{1} \mathrm{H}-\mathrm{NMR}\left(300 \mathrm{MHz}\right.$, r.t., $\mathrm{CDCl}_{3}$ ): $\delta / \mathrm{ppm} 4.60\left(\mathrm{~s}, 6 \mathrm{H}, \mathrm{CH}_{2}\right.$ ), 7.25 (s, 3H, Ar).

1,3,5-Tribenzylchloride (14). Compound $13(0.200 \mathrm{~g}, 1.19 \mathrm{mmol})$ was dissolved with $\mathrm{SOCl}_{2}(5 \mathrm{~mL})$ at $0{ }^{\circ} \mathrm{C}$ and to the solution the catalytic amount of DMF was added. The solution was stirred for $48 \mathrm{~h}$ at room temperature. The reaction was confirmed by TLC $($ EtOAc $-n$-hexane $=1: 1)$. The reaction mixture was poured into ice-water, and extracted with $\mathrm{CHCl}_{3}$. The organic phase was washed with water, and dried over $\mathrm{MgSO}_{4}$. The solution was evaporated to yield white solid; Yield $0.241 \mathrm{~g}, 93.9 \%$. ${ }^{1} \mathrm{H}-\mathrm{NMR}$ (300 MHz, r.t., $\mathrm{CDCl}_{3}$ ): $\delta / \mathrm{ppm} 4.57$ (s, 6H, $\mathrm{CH}_{2}$ ), 7.36 (s, 3H, Ar).

1,3,5-Tribenzylazide (15). Compound $14(0.214 \mathrm{~g}, 0.964 \mathrm{mmol})$ was dissolved in DMF (10 mL). $\mathrm{NaN}_{3}$ ( $1.13 \mathrm{~g}, 17.4 \mathrm{mmol}, 18 \mathrm{eq}$.) was added to the solution, and the solution was stirred at $70{ }^{\circ} \mathrm{C}$ for $21 \mathrm{~h}$. The solution was evaporated, and the residue was dissolved with chloroform. The solution was washed with $1 \mathrm{~N} \mathrm{HCl}$ aq., sat. $\mathrm{NaHCO}_{3}$, and brine. The solution was dried over $\mathrm{MgSO}_{4}$. The solution was evaporated to yield colorless oil; Yield $0.218 \mathrm{~g}, 93.0 \%$. ${ }^{1} \mathrm{H}-\mathrm{NMR}\left(300 \mathrm{MHz}\right.$, r.t., $\mathrm{CDCl}_{3}$ ): $\delta / \mathrm{ppm} 4.38$ (s, 6H, $\mathrm{CH}_{2}$ ), 7.23 (s, 3H, Ar).

1-(3-Acetyl-5-prop-2-ynyloxy-phenyl)ethanone (17). Dimethyl 5-hydroxyisophtalate (16, $5.01 \mathrm{~g}$, $23.8 \mathrm{mmol}$ ) and $\mathrm{K}_{2} \mathrm{CO}_{3}(93 \mathrm{~g}$, $35.7 \mathrm{mmol}, 1.5$ eq.) were dissolved in DMF (100 mL), and the solution was degassed with bubbling of $\mathrm{N}_{2}$. The solution was heated up to $80^{\circ} \mathrm{C}$, and propargyl bromide $(2.80 \mathrm{~mL}$, $35.7 \mathrm{mmol}, 1.5$ eq.) was added under $\mathrm{N}_{2}$. The solution was stirred for overnight. The solution was allowed to be cooled to room temperature. $\mathrm{K}_{2} \mathrm{CO}_{3}$ was removed by filtration, and the solution was evaporated. The residue was recrystallized in $\mathrm{EtOH}$ to yield white solid; Yield: $4.52 \mathrm{~g}, 76.5 \%$. ${ }^{1} \mathrm{H}-\mathrm{NMR}$ (300 MHz, r.t., $\left.\mathrm{CDCl}_{3}\right): \delta / p p m 2.53(\mathrm{t}, J=2.1 \mathrm{~Hz}, J=2.4 \mathrm{~Hz}, 1 \mathrm{H}, \mathrm{C} \equiv \mathrm{CH}), 3.92\left(\mathrm{~s}, 6 \mathrm{H}, \mathrm{CH}_{3}\right), 4.76(\mathrm{~d}$, $\left.J=2.4 \mathrm{~Hz}, 2 \mathrm{H}, \mathrm{CH}_{2}\right), 7.80(\mathrm{~d}, J=1.5 \mathrm{~Hz}, 2 \mathrm{H}, \mathrm{ArH}), 8.30(\mathrm{t}, J=1.5 \mathrm{~Hz}, J=1.2 \mathrm{~Hz}, 1 \mathrm{H}, \mathrm{ArH})$.

(3-Hydroxymethyl-5-prop-2-ynyloxy-phenyl)methanol (18). Compound 17 (0.500 g, $2.01 \mathrm{mmol})$ was dissolved in THF $(35.0 \mathrm{~mL})$, and degassed. $\mathrm{LiAlH}_{4}(12.1 \mathrm{mmol})$ was added to the solution. The reaction mixture was stirred for $6 \mathrm{~h}$, and the reaction was confirmed by TLC (EtOAc- $n$-hexane $=1: 1$ ). Then, water was added to the solution in order to quench the reaction. The solution was dried over $\mathrm{MgSO}_{4}$, and $\mathrm{MgSO}_{4}$ was removed by filtration. The solution was evaporated to yield white solid; Yield 0.425 g, 99\%. ${ }^{1} \mathrm{H}-\mathrm{NMR}\left(300 \mathrm{MHz}\right.$, r.t., $\mathrm{CD}_{3} \mathrm{OD}$ ): $\delta / \mathrm{ppm} 2.91$ (t, $J=2.7 \mathrm{~Hz}, J=2.4 \mathrm{~Hz}, 1 \mathrm{H}, \mathrm{C} \equiv \mathrm{CH}$ ), 4.57 (s, 4H, $\left.\mathrm{CH}_{2} \mathrm{OH}\right), 4.72\left(\mathrm{~d}, J=2.4 \mathrm{~Hz}, 2 \mathrm{H}, \mathrm{CH}_{2}\right), 6.89$ (s, 2H, ArH), 8.30 (d, J=0.6 Hz, 1H, ArH).

1,3-Bischloromethyl-5-prop-2-ynyloxy-benzene (19). Compound $18(0.425 \mathrm{~g}, 2.21 \mathrm{mmol})$ was dissolved in $\mathrm{CH}_{2} \mathrm{Cl}_{2}$, and $\mathrm{SOCl}_{2}$ was added to the solution with catalytic amount of DMF at $0{ }^{\circ} \mathrm{C}$. The reaction 
mixture was stirred for overnight, and the reaction was confirmed by TLC (EtOAc- $n$-hexane $=1: 1$ ). The reaction mixture was poured into ice-water, and extracted with $\mathrm{CHCl}_{3}$. The organic phase was washed with water, and dried over $\mathrm{MgSO}_{4} \cdot \mathrm{MgSO}_{4}$ was removed by filtration, and the solution was evaporated to yield white solid; Yield. $0.462 \mathrm{~g}, 91.2 \%$. ${ }^{1} \mathrm{H}-\mathrm{NMR}\left(300 \mathrm{MHz}\right.$, r.t., $\mathrm{CDCl}_{3}$ ): $\delta / \mathrm{ppm} 2.52$ (t, $J=2.4 \mathrm{~Hz}, J=2.4 \mathrm{~Hz}, 1 \mathrm{H}, \mathrm{C} \equiv \mathrm{CH}), 4.53\left(\mathrm{~s}, 4 \mathrm{H}, \mathrm{CH}_{2}\right), 4.70\left(\mathrm{~d}, J=2.4 \mathrm{~Hz}, 2 \mathrm{H}, \mathrm{CH}_{2}\right), 6.95(\mathrm{~d}$, $J=1.5 \mathrm{~Hz}, 2 \mathrm{H}, \mathrm{ArH}), 7.02$ (t, $J=0.6 \mathrm{~Hz}, J=0.6 \mathrm{~Hz}, 1 \mathrm{H}, \mathrm{ArH})$.

G1-Cl (20). Compounds $15(95.0 \mathrm{mg}, 0.391 \mathrm{mmol})$ and $19(0.420 \mathrm{~g}, 1.83 \mathrm{mmol})$ was dissolved in DMF (3 mL). To the reaction mixture, CuI (111 mg, $0.586 \mathrm{mmol})$ was added and suspended. DIEA $(100 \mathrm{~mL}, 0.588 \mu \mathrm{mol})$ was added to the solution. The solution was stirred for $24 \mathrm{~h}$. The reaction mixture was evaporated, and the residue was purified by column chromatography $\left(\mathrm{CHCl}_{3}-\mathrm{MeOH}=60: 1\right)$ to yield white solid; Yield $0.268 \mathrm{~g}, 73.7 \%$. ${ }^{1} \mathrm{H}-\mathrm{NMR}\left(300 \mathrm{MHz}\right.$, r.t., $\left.\mathrm{CDCl}_{3}\right)$ : $\delta / \mathrm{ppm} 4.50\left(\mathrm{~s}, 12 \mathrm{H}, \mathrm{CH}_{2}\right.$ ), $5.20\left(\mathrm{~s}, 6 \mathrm{H}, \mathrm{CH}_{2}\right), 5.46\left(\mathrm{~s}, 6 \mathrm{H}, \mathrm{CH}_{2}\right), 6.94(\mathrm{~s}, 6 \mathrm{H}, \mathrm{ArH}), 6.99$ (s, 3H, ArH), 7.10 (s, 3H, ArH), 7.54 $(\mathrm{s}, 3 \mathrm{H}, \mathrm{C}=\mathrm{CH})$.

G1- $\boldsymbol{N}_{3}$ (21). Compound 20 (0.268 g, $\left.0.288 \mathrm{mmol}\right)$ was dissolved in DMF (10 mL). NaN 3 (3.63 mmol) was added to the solution, and the solution was stirred at $50{ }^{\circ} \mathrm{C}$ for overnight. The solution was evaporated, and the residue was dissolved in $\mathrm{CHCl}_{3}$. The organic phase was washed with water for three times. The solution was dried with $\mathrm{MgSO}_{4}$, and $\mathrm{MgSO}_{4}$ was removed by filtration. The residue was purified by column chromatography $\left(\mathrm{CHCl}_{3}-\mathrm{MeOH}=100: 1\right)$ to yield white solid; Yield $0.260 \mathrm{~g}$, 93.1\%. ${ }^{1} \mathrm{H}-\mathrm{NMR}\left(300 \mathrm{MHz}\right.$, r.t., $\left.\mathrm{CDCl}_{3}\right): \delta / \mathrm{ppm} 4.29\left(\mathrm{~s}, 12 \mathrm{H}, \mathrm{CH}_{2}\right), 5.21\left(\mathrm{~s}, 6 \mathrm{H}, \mathrm{CH}_{2}\right), 5.45(\mathrm{~s}, 6 \mathrm{H}$, $\left.\mathrm{CH}_{2}\right), 6.85$ (s, 3H, ArH), 6.88 (s, 6H, ArH), 7.13 (s, 3H, ArH), 7.55 (s, 3H, C=CH). ${ }^{1} \mathrm{H}-\mathrm{NMR}(300 \mathrm{MHz}$, r.t., DMF-d $\left.\mathrm{d}_{7}\right): \delta / \mathrm{ppm} 4.50\left(\mathrm{~s}, 12 \mathrm{H}, \mathrm{CH}_{2}\right) 5.23\left(\mathrm{~s}, 6 \mathrm{H}, \mathrm{CH}_{2}\right), 5.71\left(\mathrm{~s}, 6 \mathrm{H}, \mathrm{CH}_{2}\right), 7.05(\mathrm{~s}, 3 \mathrm{H}, \mathrm{ArH}), 7.10$ (s, 6H, ArH), 7.45 (s, 3H, ArH), 8.39 (s, 3H, C=CH). ${ }^{13} \mathrm{C}-\mathrm{NMR}\left(75 \mathrm{MHz}\right.$, r.t., $\left.\mathrm{CDCl}_{3}\right): \delta / \mathrm{ppm} 53.4,54.4$, 62.1, 114.3, 120.6, 122.9, 127.6, 136.8, 137.7, 144.4, 158.8. ESI-MS: m/z 969.9.0 [M+H] $]^{+}, 992.0[\mathrm{M}+\mathrm{Na}]^{+}$.

pNP 6-Sulfo-GlcNAc hexamer(G1:22). Compounds 21 (6.15 mg, $6.34 \mu \mathrm{mol})$ and $\mathbf{1 0}$ were dissolved in DMF $(400 \mu \mathrm{L})$, and an aqueous solution of sodium ascorbate $(6.02 \mathrm{mg}, 0.0304 \mathrm{mmol})$ and $\mathrm{CuSO}_{4}$ ( $2.40 \mathrm{mg}, 0.0150 \mathrm{mmol}$ ) was added to the solution. The reaction mixture was stirred for 3 days. The solvent was evaporated and the residue was purified by reversed phase chromatography $\left(\mathrm{H}_{2} \mathrm{O}-\mathrm{MeOH}=2: 1\right)$ to yield a white solid; Yield $7.70 \mathrm{mg}, 28.2 \%$. ${ }^{1} \mathrm{H}-\mathrm{NMR}$ (300 MHz, r.t., DMF- $\left.d_{7}\right): \delta / \mathrm{ppm} 1.26-1.28(\mathrm{~m}, 12 \mathrm{H}$, $\left.\mathrm{CH}_{2}\right), 1.88\left(\mathrm{~s}, 18 \mathrm{H}, \mathrm{OCOC}_{3}\right), 1.96\left(\mathrm{t}, J=7.5 \mathrm{~Hz}, J=7.5 \mathrm{~Hz}, 12 \mathrm{H}, \mathrm{CH}_{2}\right), 2.41$ (t, $J=7.5 \mathrm{~Hz}, J=7.8 \mathrm{~Hz}$, $\left.12 \mathrm{H}, \mathrm{CH}_{2}\right), 3.92\left(\mathrm{dd}, J_{\mathrm{H} 1-\mathrm{H} 2}=9.5 \mathrm{~Hz}, J_{\mathrm{H} 2-\mathrm{H} 3}=9.0 \mathrm{~Hz}, 6 \mathrm{H}, \mathrm{H} 2\right), 4.03-4.06(\mathrm{~m}, 6 \mathrm{H}, \mathrm{H} 5), 4.07-4.11(\mathrm{~m}, 6 \mathrm{H}$, H3), 4.19-4.26 (m, 6H, H4), $5.02\left(\mathrm{~d}, J_{\mathrm{H} 1-\mathrm{H} 2}=9.0 \mathrm{~Hz}, 6 \mathrm{H}, \mathrm{H} 1\right), 5.16\left(\mathrm{~s}, 6 \mathrm{H}, \mathrm{CH}_{2}\right), 5.29$ (broad, 6H, H6), 5.36 (broad, 6H, H6), $5.57\left(\mathrm{~s}, 12 \mathrm{H}, \mathrm{CH}_{2}\right), 5.66\left(\mathrm{~s}, 6 \mathrm{H}, \mathrm{CH}_{2}\right), 6.91(\mathrm{~s}, 3 \mathrm{H}, \mathrm{ArH}), 6.94(\mathrm{~d}, 12 \mathrm{H}$, $\left.J_{\mathrm{o}-\mathrm{m}}=9.0 \mathrm{~Hz}, \mathrm{Ph}-\mathrm{o}\right), 7.03$ (s, 6H, ArH), 7.44 (s, 3H, ArH), 7.58 (d, 12H, $\left.J_{\mathrm{o}-\mathrm{m}}=9.0 \mathrm{~Hz}, \mathrm{Ph}-\mathrm{m}\right), 7.94$ (s, $6 \mathrm{H}, \mathrm{C}=\mathrm{CH}), 8.40(\mathrm{~s}, 3 \mathrm{H}, \mathrm{C}=\mathrm{CH}) .{ }^{13} \mathrm{C}-\mathrm{NMR}\left(75 \mathrm{MHz}\right.$, r.t., DMF-d $\left.\mathrm{d}_{7}\right): \delta / \mathrm{ppm} 23.5,28.2,30.6,31.0$, $47.9,58.4,59.8,61.8,67.1,71.7,76.8,80.4,81.2,106.0,115.2,119.8,122.5,126.0,130.6,133.6$, $140.1,143.1,144.2,159.4,164.6,175.5,176.4$. ESI-MS: $m / z 822.9[\mathrm{M}+\mathrm{H}+4 \mathrm{Na}]^{5+}$.

G2-Cl (23). G1-N $3(21,0.0597 \mathrm{~g}, 0.0616 \mathrm{mmol})$ and 19 (0.114 g, $0.498 \mathrm{mmol})$ was dissolved in DMF $(750 \mu \mathrm{L}) . \mathrm{CuI}(21.0 \mathrm{mg}, 0.110 \mathrm{mmol})$ was added to the solution and suspended. DIEA was added to the solution, and the solution was stirred for $24 \mathrm{~h}$ at room temperature. The reaction was confirmed 
by TLC $\left(\mathrm{CHCl}_{3}-\mathrm{MeOH}=10: 1\right)$, and the residue was purified by column chromatography $\left(\mathrm{CHCl}_{3}-\mathrm{MeOH}=40: 1\right)$ to yield a white solid; Yield $43.5 \mathrm{mg}, 30.1 \%$. ${ }^{1} \mathrm{H}-\mathrm{NMR}$ (300 MHz, r.t., $\mathrm{CDCl}_{3}$ ): $\delta / \mathrm{ppm} 4.45\left(\mathrm{~s}, 24 \mathrm{H}, \mathrm{CH}_{2}\right), 4.99\left(\mathrm{~s}, 6 \mathrm{H}, \mathrm{CH}_{2}\right), 5.07\left(\mathrm{~s}, 12 \mathrm{H}, \mathrm{CH}_{2}\right), 5.12\left(\mathrm{~s}, 6 \mathrm{H}, \mathrm{CH}_{2}\right), 5.37$ (s, 12H, $\left.\mathrm{CH}_{2}\right), 6.73$ (s, 3H, ArH), $6.75(\mathrm{~s}, 6 \mathrm{H}, \mathrm{ArH}), 6.88(\mathrm{~s}, 12 \mathrm{H}, \mathrm{ArH}), 6.94(\mathrm{~s}, 6 \mathrm{H}, \mathrm{ArH}), 7.05(\mathrm{~s}, 3 \mathrm{H}$, $\operatorname{ArH}), 7.55(\mathrm{~s}, 3 \mathrm{H}, \mathrm{C}=\mathrm{CH}), 7.62(\mathrm{~s}, 6 \mathrm{H}, \mathrm{C}=\mathrm{CH})$.

G2-N $N_{3}$ (24). 23 (0.0435 g, $\left.0.0186 \mathrm{mmol}\right)$ was dissolved in DMF (10 mL). $\mathrm{NaN}_{3}(0.0201 \mathrm{~g}, 0.334 \mathrm{mmol})$ was added to the solution, and stirred at $50{ }^{\circ} \mathrm{C}$ for overnight. The solution was evaporated and the residue was dissolved in $\mathrm{CHCl}_{3}$. The organic phase was washed with water three times. The organic phase was dried over $\mathrm{MgSO}_{4}$, and $\mathrm{MgSO}_{4}$ was filtrated. The residue was purified by column chromatography $\left(\mathrm{CHCl}_{3}-\mathrm{MeOH}=40: 1\right)$ to yield a white solid; Yield $0.253 \mathrm{~g}, 56.3 \% .{ }^{1} \mathrm{H}-\mathrm{NMR}(300 \mathrm{MHz}$, r.t., $\mathrm{CDCl}_{3}$ ): $\delta / \mathrm{ppm} 4.27\left(\mathrm{~s}, 24 \mathrm{H}, \mathrm{CH}_{2}\right), 4.5 .04\left(\mathrm{~s}, 6 \mathrm{H}, \mathrm{CH}_{2}\right), 5.16\left(\mathrm{~s}, 12 \mathrm{H}, \mathrm{CH}_{2}\right), 5.17\left(\mathrm{~s}, 6 \mathrm{H}, \mathrm{CH}_{2}\right)$, $5.40\left(\mathrm{~s}, 12 \mathrm{H}, \mathrm{CH}_{2}\right), 6.76(\mathrm{~s}, 3 \mathrm{H}, \mathrm{ArH}), 6.78(\mathrm{~s}, 6 \mathrm{H}, \mathrm{ArH}), 6.83(\mathrm{~s}, 6 \mathrm{H}, \mathrm{ArH}), 6.86(\mathrm{~s}, 12 \mathrm{H}, \operatorname{ArH}), 7.08$ $(\mathrm{s}, 3 \mathrm{H}, \mathrm{ArH}), 7.54(\mathrm{~s}, 3 \mathrm{H}, \mathrm{C}=\mathrm{CH}), 7.61(\mathrm{~s}, 6 \mathrm{H}, \mathrm{C}=\mathrm{CH}) .{ }^{1} \mathrm{H}-\mathrm{NMR}\left(300 \mathrm{MHz}\right.$, r.t., DMF- $\left.d_{7}\right): \delta / \mathrm{ppm} 4.48$ $\left(\mathrm{s}, 24 \mathrm{H}, \mathrm{CH}_{2}\right), 5.15\left(\mathrm{~s}, 6 \mathrm{H}, \mathrm{CH}_{2}\right), 5.24\left(\mathrm{~s}, 12 \mathrm{H}, \mathrm{CH}_{2}\right), 5.66\left(\mathrm{~s}, 6 \mathrm{H}, \mathrm{CH}_{2}\right), 5.69\left(\mathrm{~s}, 12 \mathrm{H}, \mathrm{CH}_{2}\right), 7.03$ (s, 6H, ArH), 7.06 (s, 9H, ArH), 7.09 (s, 12H, ArH), 7.44 (s, 3H, ArH), 8.35 (s, 3H, C=CH), 8.41 (s, 6H, C=CH). ${ }^{13} \mathrm{C}-\mathrm{NMR}\left(75 \mathrm{MHz}\right.$, r.t., $\left.\mathrm{CDCl}_{3}\right): \delta / \mathrm{ppm} 53.3,53.6,54.3,61.7,62.0,114.2,114.6$, 120.0, 120.6, 123.2, 123.5, 127.7, 136.7, 137.2, 137.7, 143.6, 144.1, 158.7, 159.0. MALDI-TOF-MS: $\mathrm{m} / \mathrm{z} 2447.2[\mathrm{M}+\mathrm{Na}]^{+}$.

pNP 6-Sulfo-GlcNAc dodecamer (G2:25). Compounds 24 (8.00 mg, $3.30 \mu \mathrm{mol})$ and $\mathbf{1 0}$ were dissolved in DMF $(350 \mu \mathrm{L})$. The aqueous solution $(83 \mu \mathrm{L})$ of sodium ascorbate $(6.28 \mathrm{mg}, 31.7 \mathrm{mmol})$ and $\mathrm{CuSO}_{4}(2.52 \mathrm{mg}, 0.0158 \mathrm{mmol})$ was added to the solution. The reaction mixture was stirred for 3 days. The reaction was confirmed by TLC $\left(\mathrm{H}_{2} \mathrm{O}-\mathrm{MeOH}=3: 1\right)$. The solution was evaporated and the residue was purified by reversed phase column chromatography $\left(\mathrm{H}_{2} \mathrm{O}-\mathrm{MeOH}=3: 1\right)$ to yield a white solid; Yield $6.30 \mathrm{mg}, 21.1 \%$. ${ }^{1} \mathrm{H}-\mathrm{NMR}\left(500 \mathrm{MHz}\right.$, r.t., DMF- $\left.d_{7}\right): \delta / \mathrm{ppm} 1.26-1.28\left(\mathrm{~m}, 24 \mathrm{H}, \mathrm{CH}_{2}\right), 1.88$ (s, 36H, OCOC $\left.\underline{H}_{3}\right), 1.94-199\left(\mathrm{~m}, 24 \mathrm{H}, \mathrm{CH}_{2}\right), 2.40\left(\mathrm{t}, J=7.5 \mathrm{~Hz}, J=7.0 \mathrm{~Hz}, 24 \mathrm{H}, \mathrm{CH}_{2}\right), 3.78$ (broad, 12H, H5), 3.87-3.90 (m, 12H, H2), 4.06-4.10 (m, 12H, H3), 4.23-4.26 m, 12H, H4), 4.25 (m, 6H, $\mathrm{H} 4), 5.01\left(\mathrm{~d}, J_{\mathrm{H} 1-\mathrm{H} 2}=8.5 \mathrm{~Hz}, 12 \mathrm{H}, \mathrm{H} 1\right), 5.16-5.18(\mathrm{~m}, 12 \mathrm{H}, \mathrm{H} 6), 5.22-5.24$ (broad, $\left.6 \mathrm{H}, \mathrm{CH}_{2}\right)$, 5.31-5.34 (m, 6H, H6), 5.36 (broad, 6H, H6'), $5.53\left(\mathrm{~s}, 24 \mathrm{H}, \mathrm{CH}_{2}\right), 5.56\left(\mathrm{~s}, 12 \mathrm{H}, \mathrm{CH}_{2}\right), 5.58(\mathrm{~s}, 12 \mathrm{H}$, $\mathrm{CH}_{2}$ ), 5.61-5.66 (broad, 6H, $\mathrm{CH}_{2}$ ), 6.88 (s, 6H, ArH), 6.96-6.98 (overlap, 24H, Ph-o), 6.96-6.98 (overlap, 9H, ArH), 7.03(s, 12H, ArH), 7.44 (broad, 3H, ArH), 7.58 (d, 2H, Jo-m $=8.1 \mathrm{~Hz}, \mathrm{Ph}-\mathrm{m}$ ), 7.94 $(\mathrm{s}, 12 \mathrm{H}, \mathrm{C}=\mathrm{CH}), 8.35$ (s, 3H, C=CH), $8.35(\mathrm{~s}, 6 \mathrm{H}, \mathrm{C}=\mathrm{CH}) .{ }^{13} \mathrm{C}-\mathrm{NMR}\left(75 \mathrm{MHz}\right.$, r.t., DMF- $\left.d_{7}\right): \delta / \mathrm{ppm}$ 22.6, 28.2, 30.6, 31.1, 58.4, 61.3, 61.8, 67.1, 71.7, 76.8, 80.3, 81.2, 82.3, 91.5, 106.0, 115.4, 120.0, $122.5,126.0,127.8,130.0,140.1,143.2,143.4,144.2,148.7,155.4,156.6,156.6,164.6,164.7,176.4$, 181.0. ESI-MS $m / z 1238.0[\mathrm{M}+\mathrm{H}+6 \mathrm{Na}]^{7+}$.

\subsection{Lectin Recognition Assay}

Each sugar dendrimer was dissolved in PBS ( $\mathrm{pH} 7.4$ ) at a concentration of $8.00 \mu \mathrm{M}$. The lectin (FITC-WGA) was also dissolved in PBS ( $\mathrm{pH} 7.4$ ) at a concentration of $0.100 \mu \mathrm{M}$. To a solution of WGA $(300 \mu \mathrm{L})$ were sequentially added aliquots of the sugar dendrimer solutions $(3,3,5,5,5,5,10$, $10,10,10,10,20,20$ and $20 \mu \mathrm{L}$ ) at $25^{\circ} \mathrm{C}$. Fluorescent measurements were taken 5 min after the 
addition of each aliquot. Fluorescence spectra of the FITC were measured with an excitation wavelength at $490 \mathrm{~nm}$ and an emission wavelength of $510 \mathrm{~nm}$. The PBS buffer without a sugar dendrimer was also added in the same way as a reference. Changes in the fluorescence of the sugar-protein interaction were calculated by subtracting two of fluorescence intensities (i.e., fluorescence change by sugar protein interaction $=$ fluorescence change by addition of the sugar dendrimer solution-fluorescence change by the addition of the reference PBS solution). Changes in the fluorescence were plotted according to the following formula $[19,20]$ :

$$
\frac{[S u g a r] F_{0}}{\Delta F}=\frac{[S u g a r] F_{0}}{\Delta F_{\max }}+\frac{F_{0}}{\Delta F_{\max } \cdot K_{\mathrm{a}}}
$$

where [Sugar], $\mathrm{K}_{\mathrm{a}}, \mathrm{F}_{\mathrm{o}}, \Delta \mathrm{F}$, and $\Delta \mathrm{F}$ max represent the sugar concentration of the dendrimer solution (M), the association constant $\left(\mathrm{M}^{-1}\right)$, the initial fluorescence intensity, the fluorescence change, and the maximum fluorescence change, respectively.

\subsection{In Vitro Amyloid Formation of $A \beta$ (1-42) and ThT Fluorescence Assay [14]}

$\mathrm{A} \beta$ (1-42) was dissolved in a $0.02 \%$ ammonia solution at a concentration of $200 \mu \mathrm{M}$. Any aggregates formed were removed by centrifugation using a CS120FX centrifuge (Hitachi, Tokyo, Japan) for $3 \mathrm{~h}$ at $16,000 \mathrm{~g}$ and $4{ }^{\circ} \mathrm{C}$. The supernatant was mixed with phosphate buffer $(20 \mathrm{mM}$ phosphate buffer, $\mathrm{pH} 7.4,100 \mathrm{mM} \mathrm{NaCl}$ ) to a final peptide concentration of $20 \mu \mathrm{M}$. The peptide solution was incubated with each sugar additive at $37^{\circ} \mathrm{C}$. The concentration of the sugar additives was $200 \mu \mathrm{M}$. Amyloid fibril formation was evaluated by the fluorescence emission of ThT. Following a period of incubation at $37^{\circ} \mathrm{C}$, a $5 \mu \mathrm{L}$ solution of $\mathrm{A} \beta$ in buffer was added to $300 \mu \mathrm{L}$ of the ThT solution (50 $\mathrm{mM}$ in the same phosphate buffer). Following a period of $10 \mathrm{~s}$, the fluorescence intensity was measured at an excitation wavelength of $450 \mathrm{~nm}$ and an emission wavelength of $482 \mathrm{~nm}$.

\subsection{AFM Measurements}

The $\mathrm{A} \beta$ peptide (1-42) was incubated in phosphate buffer ( $20 \mathrm{mM}$ phosphate buffer, $100 \mathrm{mM} \mathrm{NaCl}$ ) at $37{ }^{\circ} \mathrm{C}$ for $12 \mathrm{~h}$, with the peptide and the sugar additives being added at a concentration of $20 \mu \mathrm{M}$. After the incubation of the sample, a $5 \mu \mathrm{L}$ portion of the sample solution was placed on freshly cleaved mica and dried under N2. The mica substrates were then washed with $100 \mu \mathrm{L}$ of MilliQ water.

\section{Conclusions}

A series of novel glycodendrimers containing sulfonated GlcNAc have been successfully synthesized using click chemistry. The glycodendrimers of G1 and G2 formed large glycoside clusters and exhibited strong affinities to proteins of lectin and $A \beta(1-42)$ as a consequence of the multivalent effect. G1 showed the highest level of affinity to proteins because of the self-assembling properties of the dendrimer. $\mathbf{G 1}$ and $\mathbf{G 2}$ both strongly inhibited $\mathrm{A} \beta$ aggregation and $\beta$-sheet conformation.

Click chemistry was used in the current paper to successfully synthesize the glycodendrimers. The procedure was facile and proceeded without the need for protecting group chemistry. Work focused on the fabrication of functional cluster of glycosides with saccharides suitable for application in pathogens is currently underway in our laboratories. 


\section{Acknowledgments}

This work was supported by a Grand-in-Aid for Scientific Research on Innovative Areas of Soft-Interface (20106003) and by Grand-in-Aid for Young Scientists (A) (23685027).

\section{References}

1. Varki, A. Biological roles of oligosaccharides: All of the theories are correct. Glycobiology 1993, 3, 97-130.

2. Baskaran, S.; Grande, D.; Sun, X.L.; Yayon, A.; Chaikof, E.L. Glycosaminoglycan-mimetic biomaterials. 3. Glycopolymers prepared from alkene-derivatized mono-and disaccharide-based glycomonomers. Bioconjug. Chem. 2002, 13, 1309-1313.

3. Mammen, M.; Choi, S.K.; Whitesides, G.M. Polyvalent interactions in biological systems: Implications for design and use of multivalent ligands and inhibitors. Angew. Chem. Int. Ed. 1998, 37, 2754-2794.

4. Lee, Y.C.; Lee, R.T. Carbohydrate-protein interactions: Basis of glycobiology. Acc. Chem. Res. 1995, 28, 321-327.

5. Fukuda, T.; Matsumoto, E.; Onogi, S.; Miura, Y. Aggregation of Alzheimer amyloid beta peptide (1-42) on the multivalent sulfonated sugar interface. Bioconjug. Chem. 2010, 21, 1079-1086.

6. Ko, K.-S.; Jaipuri, F.A.; Pohl, N.L. Fluorous-based carbohydrate microarrays. J. Am. Chem. Soc. 2005, 127, 13162-13163.

7. Liang, P.H.; Wu, C.Y.; Greenberg, W.; Wong, C.H. Glycan arrays: Biological and medical applications. Curr. Opin. Chem. Biol. 2008, 12, 86-92.

8. Miura, Y.; Sasao, Y.; Dohi, H.; Nishida, Y.; Kobayashi, K. Self-assembled monolayers of globotriaosylceramide (Gb3) mimics: Surface-specific affinity with Shiga toxins. Anal. Biochem. 2002, 310, 27-35.

9. Nagahori, N.; Abe, M.; Nishimura, S.I. Structural and functional glycosphingolipidomics by glycoblotting with aminooxy-functionalized gold nanoparticle. Biochemistry 2009, 48, 583-594.

10. Osaki, F.; Kanamori, T.; Sando, S.; Sera, T.; Aoyama, Y. A quantum dot conjugated sugar ball and its cellular uptake. On the size effects of endocytosis in the subviral region. J. Am. Chem. Soc. 2004, 126, 6520-6521.

11. Otsuka, H.; Akiyama, Y.; Nagasaki, Y.; Kataoka, K. Quantitative and reversible lectin-induced association of gold nanoparticles modified with $\alpha$-lactosyl- $\omega$-mercapto-poly (ethylene glycol). J. Am. Chem. Soc. 2001, 123, 8226-8230.

12. Miura, Y. Synthesis and biological application of glycopolymers. J. Polym. Sci. A1 2007, 45, 5031-5036.

13. Chabre, Y.M.; Roy, R. Recent trends in glycodendrimer syntheses and application. Curr. Top. Med. Chem. 2008, 8, 1237-1285.

14. Miura, Y.; Yasuda, K.; Yamamoto, K.; Koike, M.; Nishida, Y.; Kobayashi, K. Inhibition of Alzheimer amyloid aggregation with sulfonated glycopolymers. Biomacromolecules 2007, 8, 2129-2134.

15. Miura, Y.; Mizuno, H. Interaction analyses of Amyloid b peptide (1-40) with glycosaminoglycan model polymers. Bull. Chem. Soc. Jpn. 2010, 83, 1004-1009. 
16. Rostovtsev, V.V.; Green, L.G.; Fokin, V.V.; Sharpless, K.B. A stepwise huisgen cycloaddition process: Copper(I)-catalyzed regioselective "ligation" of azides and terminal alkynes. Angew. Chem. Int. Ed. 2002, 41, 2596-2599.

17. Rice, R.H.; Etzler, M.E. Chemical modification and hybridization of wheat germ agglutinins. Biochemistry 1975, 14, 4093-4099.

18. Nagata, Y.; Burger, M.M. Wheat germ agglutinin: Molecular characteristic and specificity for sugar binding. J. Biol. Chem. 1974, 249, 3116-3122.

19. Wu, P.; Malkoch, M.; Hunt, J.N.; Vestberg, R.; Kaltgrad, E.; Finn, M.G.; Fokin, V.V.; Sharpless, K.B.; Hawker, C.J. Multivalent, Bifunctional dendrimers prepared by click chemistry. Chem. Commun. 2005, 5775-5777.

20. Miura, Y.; Yamauchi, T.; Sato, H.; Fukuda, T. The self-assembled monolayer of saccharide via click chemistry: Formation and protein recognition. Thin Solid Films 2008, 516, 2443-2449.

21. Miura, Y.; Ikeda, T.; Kobayashi, K. Chemoenzymatically synthesized glycoconjugate polymers. Biomacromolecules 2003, 4, 410-415.

22. Zanini, D.; Roy, R. Chemoenzymatic synthesis and lectin binding properties of dendritic $N$-acetyllactosamine. Bioconjugate Chem. 1997, 8, 187-192.

23. Schwefel, D.; Maierhofer, C.; Beck J.G.; Seeberger, S.; Diederichs, K.; Möller, H.M.; Welte, W.; Wittmann, V. Structural basis of multivalent binding to wheat germ agglutinin. J. Am. Chem. Soc. 2010, 132, 8704-8719.

24. Wright, C.S. $2.2 \AA$ Resolution structure analysis of two refined $N$-acetylneuraminyl-lactose-wheat germ agglutinin isolectin complexes. J. Mol. Biol. 1990, 215, 635-651.

25. Levine, H., III. Thioglavine T interaction with synthetic Alzheimer's disease $\beta$-amyloid peptides: Detection of amyloid aggregation in solution. Prot. Sci. 1993, 2, 404-410.

26. Giulian, D.; Haverkamp, L.J.; Yu, J.; Kazanskaia, A.; Kirkpatrick, J.; Roher, A.E. The HHQK domain of $\beta$-amyloid provies a structural basis for the immunopathology of Alzheimer's disease. J. Biol. Chem. 1998, 273, 29719-29726.

27. Kitano, H.; Saito, D.; Kamada, T.; Gmmei-Ide, M. Binding of b-amyloid to sulfated sugar residues in a polymer brush. Collid. Surf. B. Biointerface 2001, 93, 9-225.

28. Fukuda, T.; Kawamura, M.; Mizuno, H.; Miura, Y. Glycosaminoglycan Model Polymers with poly( $\gamma$-glutamate) backbone to inhibit aggregation of $\beta$-amyloid peptide. Polym. J. 2012, doi:10.1038/pj.2012.147.

29. Yankner, B.A.; Duffy, L.K.; Kirschner, D.A. Neurotropic and neurotoxic effects of amyloid beta protein: Reversal by tachykinin neuropeptides. Science 1990, 250, 279-282.

30. Roychaudhuri, R.; Yang, M.; Hoshi, M.; Teplow, D.B. Amyloid b-protein assembly and Alzheimer disease. J. Biol. Chem. 2009, 284, 4749-4753.

Sample Availability: Samples of the compounds (G0, G1 and G2) are available from the authors.

(C) 2012 by the authors; licensee MDPI, Basel, Switzerland. This article is an open access article distributed under the terms and conditions of the Creative Commons Attribution license (http://creativecommons.org/licenses/by/3.0/). 